\title{
The Military Standing of the Countries in Latin America and the Caribbean Region in the Period Between 2008-2020
}

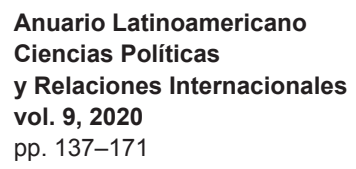

DOI: 10.17951/al.2020.9.137-171

\section{La posición militar de los países de la región de América Latina y el Caribe en el periodo 2008-2020}

\author{
Ireneusz Topolski* \\ FACULTY OF POLITICAL SCIENCE AND JOURNALISM \\ MARIA CURIE-SKŁODOWSKA UNIVERSITY \\ LUBLIN, POLAND \\ $\triangle$ ireneusz.topolski@poczta.umcs.lublin.pl \\ https://orcid.org/0000-0001-7152-8329
}

\begin{abstract}
International military position of a country may primarily be described in quantitative categories. In the case of Latin America and the Caribbean, there are several factors which condition this assessment. The most important ones seem to be: external and internal threats for a state's national security, including non-military threats, mainly of cross-border nature, international military stature of the United States of America, historical and cultural background, the role that the army plays in home affairs, modernization of armed forces, new types of combat missions or military operations, and geographical conditions. This paper analyzes the standings of land, air, and naval forces, as well as paramilitary formations in Latin America and the Caribbean in the period between 2008-2020.
\end{abstract}

KEYWORDS: Latin America and the Caribbean, military position, land forces, air forces, naval forces, paramilitary formations.

\section{RESUMEN}

La posición militar internacional de un Estado puede describirse principalmente en categorías cuantitativas. En el caso de la región de América Latina y el Caribe, hay también otros determinantes que influyen en la evaluación de la posición militar de los países. Los más importantes parecen ser: las amenazas externas e internas a la

* Post-doctoral degree in Political Science. Assistant Professor at the Department of International Relations of the Faculty of Political Science and Journalism at the Maria CurieSkłodowska University in Lublin. 
seguridad nacional, incluidas las amenazas no militares de carácter transfronterizo, la posición militar internacional de los Estados Unidos de América, el contexto histórico y cultural, el papel de los militares en la política interna, la modernización del ejército, las nuevas tareas de las fuerzas armadas y las condiciones geográficas. En este artículo se analizará la posición de las fuerzas terrestres, aéreas, navales, así como de las formaciones paramilitares de los países de la región en el período 2008-2020.

PALABRAS CLAVE: América Latina y el Caribe, posición militar, fuerzas terrestres, fuerzas aéreas, fuerzas navales, formaciones paramilitares.

\section{Introduction}

In this article we are going to describe the military stature of the countries of Latin America and the Caribbean ${ }^{1}$ in the years 2008-20202. Due to space limitations, the detailed description of the armed forces had to be omitted (International Institute for Strategic Studies (IISS) and Stockholm International Peace Research Institute (SIPRI) only include some of the countries).

The present article is predominantly descriptive, and it is written from the point of view of comparison of the countries in the region. What is more, in the case of the Caribbean sub-region we only took into account specific countries. It must be born in mind that the specificity of the region in question conditions the description of the military position of the countries in Latin America and the Caribbean. The issue revolving around the analysis of a new role that military personnel play in domestic policy (political systems) has only been signaled here since the core of the whole matter of this work focuses on the comparison of the military position of these countries. We have analyzed the armed forces in the following order: land, air, naval and paramilitary forces. Only the basic types of equipment were included in the analysis since personal weapons and light armament are virtually incomparable because they are not included in any available statistical data.

The decision to present only the international military stature in the Latin America and the Caribbean region, without comparing it to countries from other regions, especially the United States, was made consciously - the exception being the involvement in the United Nations peacekeeping operations.

The international military stature of a given country may primarily be described in quantitative categories. Qualitative factors are, in effect, extremely difficult or completely impossible to measure. Moreover, their change dyna-

1 The notion and borders of the region, see: K. Krzywicka, 2009, pp. 211-216; The Military Balance 2020, 2020, pp. 532-533.

2 Due to the data availability, points relating to the military expenditure, export and import of military equipment will be characterized in the period between 2008-2019. 
mics is quite significant. To these dynamic variations belong: professionalism in the army and its ethnic and religious structure, which is reflected in the army's ability to endure suffering and the society's will to fight (Topolski, 2004, pp. 22-23).

The aim of this work is to provide a concise summary of the military strength of the Latin American and Caribbean countries. In doing so, we have adopted the following hypotheses:

1. Land forces and paramilitary formations exert the greatest influence on the aggregate military standing of the Latin American and Caribbean countries.

2. Brazil occupies the first place in the region as far as the military strength goes.

\section{Conditions relating to the military position of the countries of Latin America and the Caribbean}

In the case of the Latin American and Caribbean countries, several conditions, which greatly impact their capabilities, need to be considered. This directly translates into the military position of a country in the region. The first condition included in our analysis is the external and internal threat to the security of a country. These threats trigger numerous contradictions since, on the one hand, a region may be described as stable or as the one in which the possibility of an international, armed conflict outbreak is relatively low. According to the provisions of the Tlatelolco Treaty, signed in 1967 (it took effect in 1969), Latin America is a zone free of nuclear weapons. At the same time, there exist multiple territorial and border disputes which could be defined as long-standing They date back to the decolonization period and the process of forming independent countries in the first part of the $19^{\text {th }}$ century, as well as the influence of the then Creole elites on the subsequent forming of borders. These disputes are of sub-regional nature and they do not pose any direct military threat. However, they might potentially stir an armed conflict. The most significant ones include:

a) Venezuela and Guyana territorial dispute with Colombia over Esequiba (approximately $142000 \mathrm{~km}^{2}$ ),

b) the issue of Bolivia's access to the Pacific Ocean - dispute with Chile,

c) the Falkland Islands sovereignty dispute between Argentina and Great Britain,

d) border disputes in Central America (Belize-Guatemala) (Kruijt, 2017, pp. 7-9; Goldblat, 1994, pp. 326-342; Krzywicka, 2012c, pp. 17-18; Lisińska, 2017, pp. 529-532; Czerny, 2015, pp. 37-39; Czerny and Czerny, 2017b, pp. 47-49; Czerny and Czerny, 2017a, p. 183; Łaciński, 2017, p. 9; Tulchin, 2019, p. 93).

Secondly, the USA maintains an indisputable, world military power position compared to the countries in the region. In case of a direct military engagement with Latin American countries, their armies would be beaten
The Military Standing of the Countries in Latin America and the Caribbean Region in the Period Between 2008-2020

Ireneusz Topolski 
quickly by the American forces (Kruijt, 2017, p. 11; Łaciński, 2017, p. 15). Furthermore, the strategic importance of the Panama Canal to the USA needs to be indicated here (Czerny, 2015, p. 42).

Thirdly, in Latin America and the Caribbean, there are internally motivated, non-military threats, which are mainly of cross-border nature. Consequently, not only do they constitute a major threat for the internal security of a considerable number of countries in this region, but they also pose risk region-wide. These include:

a) organized crime (also cross-border crime which includes private-run armies of criminals) - this is proven by the world highest rate of crime and violence committed (including the number of murders) per 100000 inhabitants. They are largely connected with bloodletting and gang rivalry, for instance drug cartels. These structures focus on drug trafficking (which is the biggest cross-border issue), human trafficking, arms trade, mass theft and kidnappings. To some extent, the above issues concern all countries in Latin America and the Caribbean.

b) the activity of various non-public entities of paramilitary nature, including guerillas, which control parts of a country's territory, for example, Revolutionary Armed Forces of Colombia (FARC) ${ }^{3}$ and National Liberation Army (ELN) in Colombia or Shining Path (Sendero Luminoso) in Peru. These entities also comprise self-defense and private militia forces, as well as narcoparamilitares formations. These structures are directly or indirectly related to the "narcotrafficking industry" from which they benefit financially, for example, in exchange for offering "paid protection". What is more, these organizations also use violence towards citizens/inhabitants, which, in turn, causes migrations or even mass migrations (Kruijt, 2017, pp. 20, 25-27; Martynov and Moloeznik, 2017, pp. 184-192; Lisińska, 2017, pp. 529-538, 541; Hinz, 2019, pp. 21-23; Gil, 2012, pp. 116-122; Łaciński, 2012, pp. 11-13; Derwich, 2019, pp. 143-146; Czerny, 2012, pp. 31-43; Czerny and Czerny, 2017b, pp. 49-50).

Countries in the region face huge problems dealing with the high rate of violence and armed crime (Hinz, 2019, pp. 21-23). In addition, guerillas operate on a relatively uninhabited and backcountry areas, which makes it extremely difficult for the state's forces (including state's armed forces) to take control over them (Lisińska, 2017, pp. 532-534).

The third group comprises historical and cultural considerations. Here, the role of the then leaders and armies in gaining independence by the countries in the region needs to be mentioned. The fierce destruction of Spanish colonial administration led to the disintegration of power structure and the advent of

3 On the $15^{\text {th }}$ of August 2017, the Colombian government officially announced that the conflict with FARC, whose armed forces surrendered their weapons to the UN representatives, ended. However, the way the treaty was implemented posed a problem (see Biczyńska, 2019, pp. 126-128). 
"political void". This gap was filled by the army which at the same time became the guarantor of a country's existence. Charismatic leaders - caudillos - descending from military ranks took power in the state. In Latin America people started to believe that the army and its "powerful men" are the guarantors of internal stability while civil elites did not rise to the occasion and were not able to deal with governing the country. In the vein of patriotism and adopted educational system, people were convinced that the armed forces are on a historic mission to defend the state and nation against internal and external threats. From the army's perspective, whenever civil politicians endangered the national interest, or state security, there had to be a military reaction. Armed forces "had custody" but de facto controlled civil authorities so that they could "save" their homeland, if need be. Later, this phenomenon was also related to exercising power by the army, both directly and indirectly. Still, armed forces endeavored to preserve the existing domestic order and even introduce essential reforms of the state (Kruijt, 2017, pp. 9-17; Krzywicka, 2012b, pp. 1516, 22-23; Krzywicka, 2012c, p. 18; Stelmach, 2012, pp. 127-130; Krzywicka, 2012a, pp. 51-68; Trefler, 2007, pp. 64-70; Trefler, 2014, pp. 10-750; Łaciński, 2012, pp. 35-41; Gocłowska-Bolek, 2019, pp. 10-11; Hinz, 2019, p. 19).

Another aspect is the role of the military. The nature of armed forces is related to the domestic and foreign policy of a country. It also involves the relationship between "a politician" and "a serviceman". Even more so, it involves the influence the army (active and retired personnel) may have on authorities. The burning issue of civil and democratic state control over the armed forces and other military structures needs to be addressed here. It is a rather complex issue since, despite democratic control over the army, in some countries of the region the army maintained a kind of "autonomy". Besides, domestic problems, such as high crime level and poverty, undermined civil politicians' trust and credibility. The "longing" for stability, powerful authority, and charismatic leaders seems to explain why the army and their members (both active and retired personnel) are so popular among the society. In some countries, as a result of democratic election, presidency was assumed by people connected with or descending from the army. These officers acting as politicians, often referred to as "politicians in uniforms", have also become a part of political elites, including political parties. What is more, active or retired army officers fill various offices in the state power structure and local administration. They also hold high positions in economic sectors (e.g. in Venezuela). Summing up, the army and its most important leaders or retired, yet still connected with the military environment servicemen, exert great influence on politics both directly and indirectly, thus dominating civil institutions, despite the operation of law which clearly lays down that civil power has authority over the armed forces (Kruijt, 2017, pp. 21-24; Krzywicka, 2012b, pp. 14, 19-23; Trefler, 2007, pp. 64-70; Olszanecka, 2018, p. 175; Stelmach, 2019, pp. 195-205; Stelmach, 2012, pp. 133, 143-144; Hinz, 2019, pp. 20-21, 25-26). According to the Latinobarómetro survey, the inhabitants of Latin America put their
The Military Standing of the Countries in Latin America and the Caribbean Region in the Period Between 2008-2020

Ireneusz Topolski 
trust in: Catholic Church (63\%), armed forces (44\% - a 6\% drop compared to $2016)$, the police (35\%), and finally, political parties (merely $13 \%)$. The greatest support for the armed forces was reported in Uruguay (62\%), Ecuador $(61 \%)$ and Brazil (58\%) while the least support for the army was reported in Venezuela (19\%), Nicaragua (22\%) and El Salvador (27\%) (Latinobarómetro, 2018, pp. 47-50).

Another thing that must be borne in mind is that the armed forces of Latin America and the Caribbean are gradually being modernized. For one thing, it can be attributed to the fact that the countries are replacing outdated, obsolete military equipment, but also, this process is triggered by the neighboring countries' arms procurements. This phenomenon can be observed in the case of: Venezuela - Colombia and Brazil, Chile - Peru and Bolivia, Peru - Ecuador (Krzywicka, 2012c, pp. 17-18; Łaciński, 2017, p. 14; Maroszek, 2009, pp. 6-11).

Another issue revolves around the army's new array of combat missions in the region, for instance, the fight against domestic enemy, i.e. anti-government groups (Kruijt, 2017, p. 9). Armed forces fulfil tasks which are more of the constabulary nature. The army's engagement in fighting the organized crime, especially drug cartels inter alia in Mexico or Colombia, is meant to provide domestic security for instance in Bolivia, Colombia, Guatemala, Nicaragua, Peru, Uruguay, and Venezuela. New combat operations of the armed forces are primarily meant to:

a) guarantee domestic security,

b) be used as auxiliary police forces,

c) be used while fighting internal threats such as terrorists or organized crime,

d) be used as intervention forces - for instance to suppress slums areas. (Kruijt, 2017, pp. 25-28; Lisińska, 2017, pp. 534-538; Krzywicka, 2012c, p. 18; Stelmach, 2012, pp. 141-144).

These missions are accompanied by the militarization of the police through building up special police formations which are heavily armed and trained to fight in town areas. As a result, the difference between a traditional national defense and internal security might not be so easy to discern.

Participation of the armed forces in social development of a country can be said to perform another crucial function. It encompasses: health care and dental care, educational, hospital, road and environmental infrastructure (Stelmach, 2019, pp. 201, 204-205; Stelmach, 2012, pp. 127-128; Krzywicka, 2012b, pp. 5, 14-18, 22-23).

Last but not least, geographical conditions in which a country is located, its lie of a land, climate, vegetation cover, precipitation, potamic (river) system and the shape of borders are all things to be considered in the discussion. The Latin American region is widely diversified as far as geographical features are concerned. There are large countries (Brazil), big countries (Argentina, Mexico), medium-sized countries (Peru), small countries (Central America), as well as micro-countries (the Caribbean sub-region). Even though the region is predominantly lowland, the Central America sub-region 
is mainly mountainous. North American Cordillera range which traverses the sub-region from Panama to Mexico is disjointed and features steep mountainsides. Further south, the Andes mountain range extends. Its considerable height differences determine the climate diversification. In Latin America and the Caribbean, there are all climate zones, i.e. equatorial climate zone (very moist), sub-tropical climate zone (moist), wet and dry tropical climate zones, both continental (dry) and marine sub-tropical zones, moderate climate zone and finally circumpolar and subpolar zones. Vegetation cover is varied because the Amazon rainforest is a region featuring equatorial forests, and Central America is covered in thick, difficult to travel forests. In some parts of the region there are mixed coniferous and deciduous forests, savannahs, steppes, deserts, semi-deserts, and alpine vegetation. The region also features a well-developed potamic (river) system. Since a lot of the areas in the region are almost inaccessible, this system plays a vital role as far as communication routes are concerned. Thus, frequently the only possible means of transport is via rivers or small planes (Czerny, 2015, pp. 37-52; Czerny and Czerny, 2017b, pp. 47-49; Czerny and Czerny, 2017a, pp. 187-188; Mata and Campos, 2001, pp. 695-716). In Latin America, land and maritime borders are long, for instance, the border between Brazil and Venezuela $(2,199 \mathrm{~km})$, Colombia and Venezuela $(2,219 \mathrm{~km})$. They run along the mountain ridges, rivers, areas covered by rainforest, or through desert terrain - the borders are partly natural. Moreover, these borders run through uninhabited areas or through areas where the population density is rather low, too. Far-flung from the main business and political life centers, cross-border areas are peripherally located, which results in road infrastructure being poorly developed. In addition, their isolation is deepened by the environmental conditions. Limited supervision of the countries (or its absence) over these areas makes it possible for the illegal activity of various entities related to organized crime to be undertaken (by drug cartels but also paramilitary armed forces) (Czerny and Czerny, 2017b, pp. 42, 47-50; Czerny and Czerny, 2017a, pp. 183, 191; Łaciński, 2017, pp. 1112). Nevertheless, in some countries, economic resources in the cross-border areas are being allocated with the aim of increasing the mobility of the army, as well as establishing military facilities and depots (Czerny, 2015, pp. 48).

To sum up, national armed forces are subject to governmental control when domestic threats are low and international threats are high. First, the region in question is largely dominated by domestic threats, which affects the procurement of proper military equipment. Secondly, in some countries of the region, there is a deficit of effective civil control over the armed forces. Thirdly, high-ranked officers and retired servicemen exert influence on the decisionmaking process in terms of domestic politics and national security. Fourthly, the army think that it is their duty to protect national interest and sovereignty, and that they are obliged to intervene when its security is breached, according to them. It needs to be stressed at this point that the function of the armed forces representatives is extremely significant. In the second decade of the $21^{\text {st }}$
The Military Standing of the Countries in Latin America and the Caribbean Region in the Period Between 2008-2020

Ireneusz Topolski 
century it was re-defined, especially the place and the influence of military personnel on interior policy, as well as their involvement in socioeconomic development of the countries. Furthermore, due to the landform and climatic conditions, as well as a lack of infrastructure in the region, it is impossible to make full use of modern, offensive weapon systems. All the above-mentioned issues directly influence the military expenditure and development of military capability of the countries in the region which, in turn, translates into the military position of the countries in Latin America and the Caribbean (Krzywicka, 2012c, pp. 17-18; Maroszek, 2009, pp. 6-11; Spyra, 2019, p. 189). It also needs mentioning that climatic conditions have an impact on military equipment and logistic support, i.e. army supply lines. The big issue for the army seems to be the ability to have proper equipment, resistant to extreme weather conditions, at their disposal.

\section{Land forces ranking}

In this part of the article we have included the Armed Forces of Cooperation (National Guard) in Venezuela in the total of Venezuelan armed forces since, officially, they are an integral part of the army; its equivalent cannot be found in other countries of the region, though (The Military Balance 2008, 2008, p. 98; The Military Balance 2009, 2009, pp. 450-451; The Military Balance 2010, 2010, pp. 465-466; The Military Balance 2011, 2011, pp. 474-475; The Military Balance 2012, 2012, pp. 470-471; The Military Balance 2013, 2013, pp. 551-552; The Military Balance 2014, 2014, pp. 489-490; The Military Balance 2015, 2015, pp. 487-488; The Military Balance 2016, 2016, pp. 487-488; The Military Balance 2017, 2017, pp. 556-557; The Military Balance 2018, 2018, pp. 505-506; The Military Balance 2019, 2019, pp. 516-517; The Military Balance 2020, 2020, pp. 532-533.). It is worth noting that Costa Rica and Panama have not been included in this compilation because they do not have an army - just paramilitary formations.

According to the IISS, the military position of the countries in Latin America and the Caribbean between 2008-2020 was greatly diversified. Brazil has the most numerous army - approximately 318,000-368,000 soldiers. Second place was occupied by Colombia whose armed forces amounted to 254,000297,000 soldiers. Mexico holds the third place with 236,000-280,000 of army personnel. Venezuela is in the fourth place with 115,000-123,000 soldiers, followed by Peru with 81,000-115,000 soldiers. However, between 2011-2015 this country had almost the same number of soldiers as Venezuela. As for the further ranks in the compilation, in the analyzed period, their positions kept changing, which stemmed from the fact that the headcount of these armies was increased or decreased. The next two places belong to Argentina (number 6 in 2008-2017 with 73,000-76,000 soldiers, number 7 since 2018 with 74,000 personnel) and Chile (number 6 since 2018 with 77,000 soldiers, 
number 7 between 2008-2017 with 59,000-65,000 soldiers). Analyzing places $8-11$ in the compilation it can be observed that significant changes took place in the case of 4 countries: Ecuador (40,000-58,000 soldiers), the Dominican Republic $(25,000-56,000)$, Cuba $(49,000)$ and Bolivia $(34,000-46,000)$. The remaining countries, namely: Uruguay (21,000-25,000 soldiers), El Salvador (15,000-25,000) and Guatemala (15,000-18 000) occupied places 12 to 14 . Honduras $(11,000-15,000)$, Paraguay $(11,000-14,000)$ and Nicaragua $(12,000-4,000)$ had slightly smaller armies at their disposal. Jamaica $(3,000-$ 6,000 soldiers), Trinidad and Tobago (3,000-4,000), Guyana (1,000-3,000), Belize (1,000-2,000), Surinam (2,000), the Bahamas and Barbados (1,000 soldiers each) - in the case of these two countries the numbers have been rounded up to a thousand (000), Antigua and Barbuda (200) and Haiti (0-2,700, between 2009-2019 - around 150 soldiers) possess armies which are relatively smaller numerically, see Table 1.

In the case of Brazil, Colombia, Mexico, Peru, Chile, Argentina, the Dominican Republic, Ecuador, El Salvador, Guatemala, Honduras and Haiti in the analyzed period of time there have been instances of both increasing and decreasing the army personnel, whereas in Venezuela, Paraguay, Jamaica, Trinidad and Tobago, Guyana and Belize only increase in the number of soldiers can be noted. In Cuba, Surinam, the Bahamas, Barbados, Antigua and Barbu$\mathrm{da}$, armies remained at the same level numerically. Three countries, i.e. Bolivia, Uruguay and Nicaragua, had their army personnel reduced. Comparing 2008 to 2020, it shows that the number of soldiers increased in Colombia, Venezuela, Chile, the Dominican Republic, El Salvador, Guatemala, Honduras, Paraguay, Jamaica, Trinidad and Tobago, Guyana, and Belize. The reduction of army personnel occurred in Brazil, Mexico, Peru, Argentina, Ecuador, Bolivia, Uruguay, and Nicaragua. At this point Brazil needs a special mention since in 2020 the number of soldiers in the army reached almost the same number as in 2008. Also, it must be noted that Mexico's army numbers decreased due to the establishment of the National Guard, to which various types of armed forces were incorporated by president Andres Manuel Lopez Obrador (Derwich, 2019, p. 146), see Table 1.

The main purpose of participating in the UN peacekeeping operations was to strengthen international position of the countries involved (Stelmach, 2012, p. 142). Taking a closer look at the involvement of the countries of the region in these missions, two conclusions may be drawn. Firstly, 19 countries of Latin America and the Caribbean participated, which is a commanding number. Nonetheless, holistic participation of army and police personnel was considerably lower than that of the leader's in this category, and apart from the year 2017, personnel involved in the United Nation's Stabilizing Mission in Haiti - MINUSTAH. In the scale of UN, it constituted between 6.6\% (in 2010) to almost 8\% (2011) between 2008-2014. A major decrease was noted between 2015-2017 (4.2-5.6\%). We would like to emphasize the fact that until 2018 the participation of army and police personnel in the UN operations amounted to approxima-
The Military Standing of the Countries in Latin America and the Caribbean Region in the Period Between 2008-2020

Ireneusz Topolski 
Artículos y ensayos

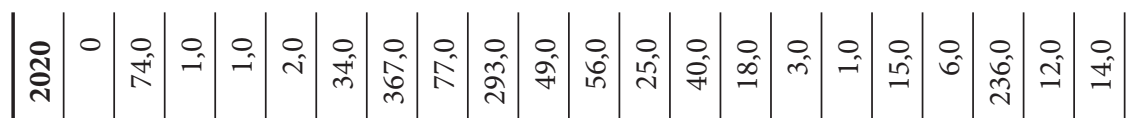

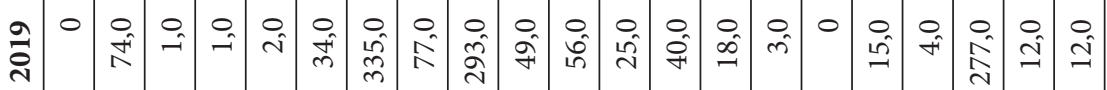

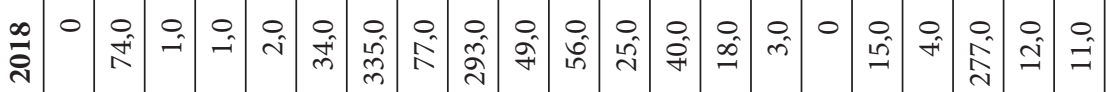

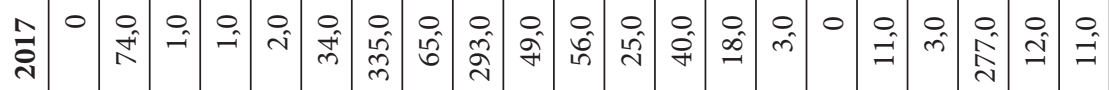

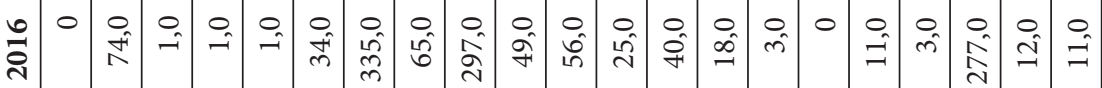

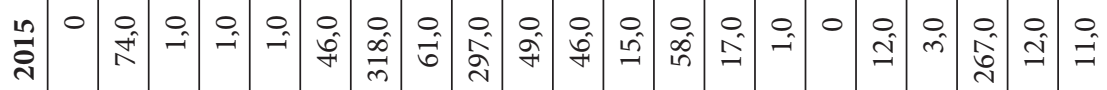

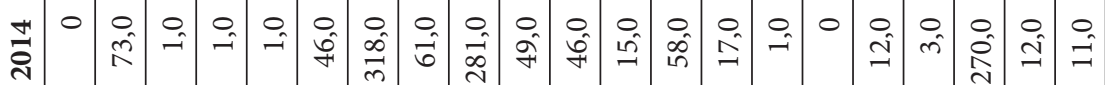

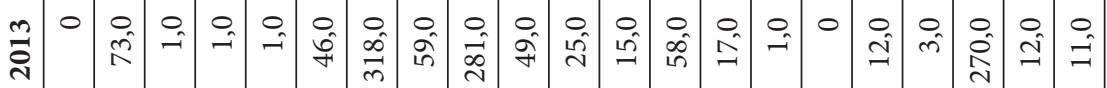

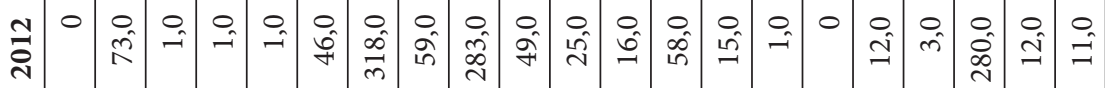

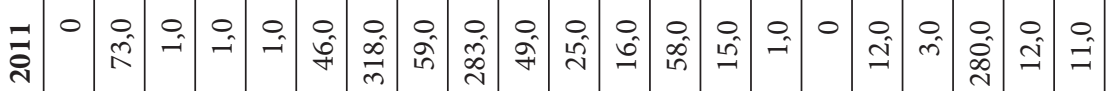

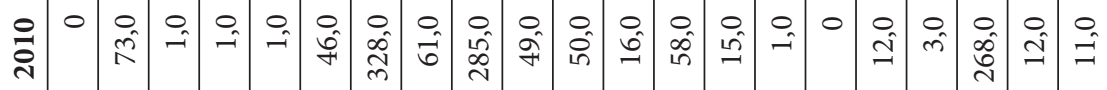

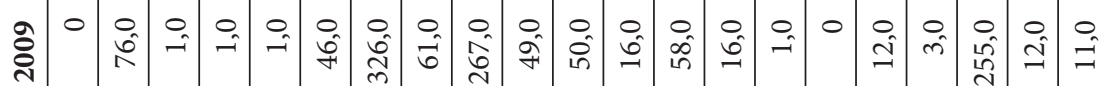

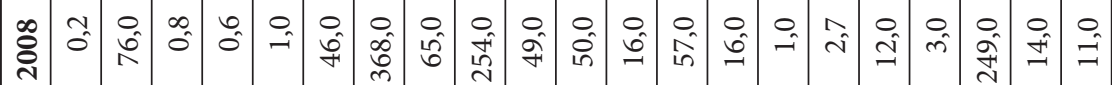

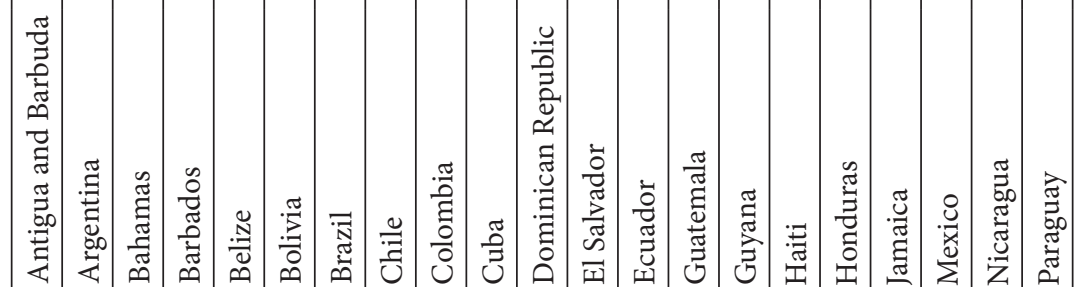

Table 1. Military strength ranking of the chosen countries of Latin America and the

Caribbean in the years 2008-2020 (in 000), according to IISS 


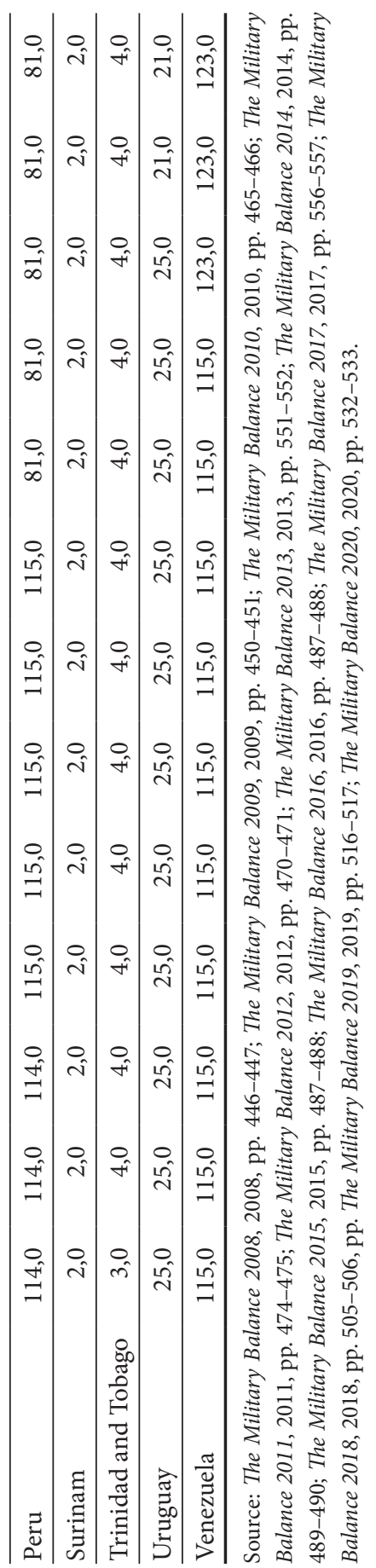

The Military Standing of the Countries in Latin America and the Caribbean Region in the Period Between 2008-2020

Ireneusz Topolski 

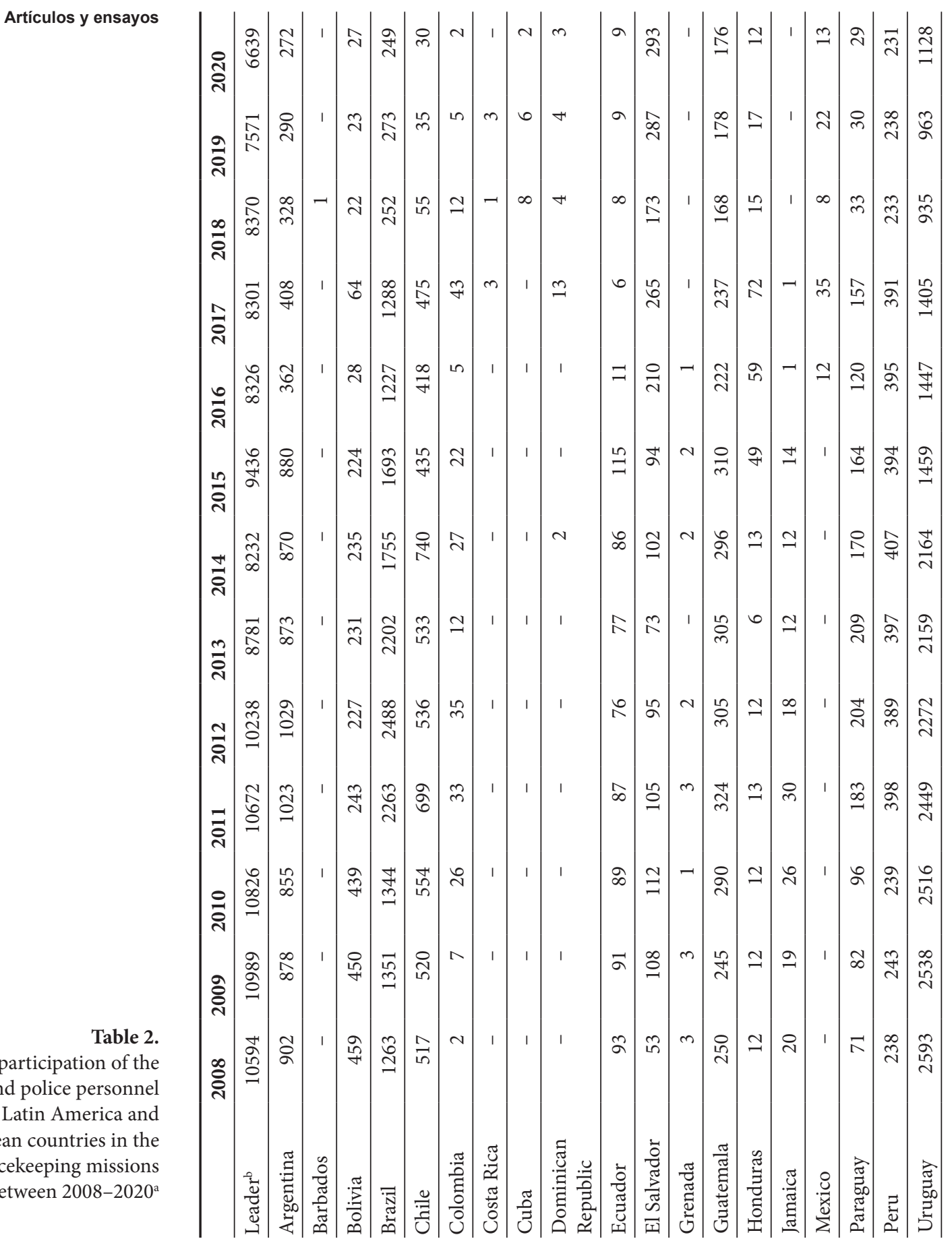

Table 2.

The participation of the army and police personnel of Latin America and Caribbean countries in the UN peacekeeping missions between 2008-2020a 


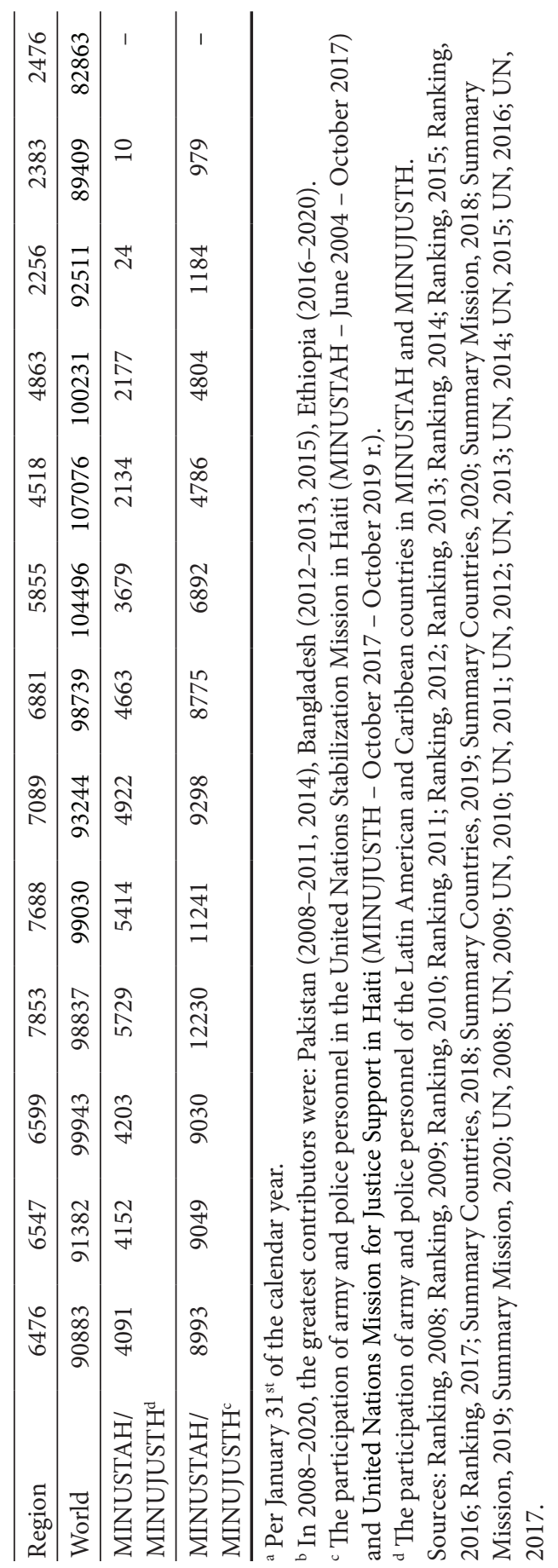

The Military Standing of the Countries in Latin America and the Caribbean Region in the Period Between 2008-2020

Ireneusz Topolski 
tely 2.4-3\%. In the case of Barbados, the Dominican Republic, Grenada, Costa Rica, and Cuba it was merely symbolic, while in the case of Jamaica, Mexico, Colombia, Honduras and Ecuador it could be described as low. At the opposite extreme, Uruguay - which may be treated as a leader in the region - needs to be mentioned. The leading countries also comprise Brazil (2008-2017), Argentina (2008-2015), and, to a lesser degree, Chile (2008-2017), Bolivia (2008-2015), as well as Paraguay (2011-2017). In the case of Peru and Guatemala, the level of involvement varied in the analyzed period. El Salvador, which as the only country significantly increased the army and police personnel participation in the UN operations, is an exception to the regional background. In 2020, it was only preceded by Uruguay (see Table 2 for reference).

Secondly, the countries of Latin America and the Caribbean most actively participated in MINUSTAH. Their contribution should be considered as significant, especially in the period between 2013-2015 when it amounted to $53-53.4 \%$ of the total number of personnel involved in the operation. In other periods of time, it remained at the level ranging from $44.4 \%$ to $48.2 \%$. After the termination of MINUSTAH, between October 2017 - October 2019, within the United Nations Mission for Justice Support in Haiti - MINUJUSTH, the involvement of the countries of the region was merely symbolic (see Table 2). To sum up, the participation of army and police personnel from Latin America and the Caribbean in the UN operations in the period between 2008-2020 was directly related to their involvement in MINUSTAH, the exception here being Uruguay - one of the greatest contributors.

Land forces constitute the most important component of the armed forces of Latin America and the Caribbean, the exception being the armed forces of the Bahamas which only comprise the naval component (The Military Balance 2020,2020 , p. 401). Determining the military ranking of land forces in the region requires, on the one hand, to include the headcount of the personnel. On the other hand, though, one also must take into the account the basic level of equipment, mainly the so-called heavy weapons. According to IISS, in 2020 Brazil, Colombia and Mexico overwhelmingly dominate the region as far as the number of soldiers is concerned. The position of Venezuela is worth noting as well - although its land forces are considerably smaller than the top three (nearly 2.6 times smaller than Colombia, 2.5 times smaller than Brazil and over twice smaller than Mexican forces), its position in the region is still strong. Comparing Venezuelan army to the other countries' armies in the region, it can be observed that its army is 1.8 times bigger than the Peruvian forces, and its advantage is much larger compared to Belize or Surinam (57-61 times). Lower positions in the ranking belong to Peru, Chile, Argentina, and Cuba. The Dominican Republic, Ecuador, Bolivia, El Salvador, Guatemala, Uruguay, and Nicaragua have numerically inferior armies. Paraguay, Honduras, Jamaica possess relatively minor forces, followed by Guyana, Trinidad and Tobago, Belize, Surinam whose land forces are even less numerous. Barbados, Haiti, Antigua and Barbuda's land forces are rather symbolic (see Table 3). 
The situation is much more complex when we include the criterion of major equipment categories, that is - heavy weapons. The greatest estimated number of tanks and anti-aircraft systems belong to Cuba. This country also owns a large number of artillery (number 3 in the ranking), and armored vehicles. In the case of Cuba, though, it must be stated that a large part of this equipment was made in the Soviet Union and dates back to $40 \mathrm{~s}, 50 \mathrm{~s}$, 60 s of the $20^{\text {th }}$ century (The Military Balance 2020, 2020, p. 416). Antigua and Barbuda, Barbados and Haiti did not have any military equipment of even basic categories. Regionwide, countries occupying lowest positions in the ranking are Belize, Surinam, Trinidad and Tobago and Guyana. Another group comprises countries such as Jamaica, Paraguay, and Honduras where, despite the disproportion in the number of army personnel or equipment, the military capability is moderately low. In the case of the Dominican Republic, Nicaragua, El Salvador, Guatemala, and Uruguay the level of military capability is below average, while Bolivia and Ecuador are close to average. Taking into the consideration both headcount of the armies and basic military equipment categories, Peru, Argentina, and Chile's military capabilities in the region can be described as average, which corresponds to the position of their land forces in the compilation. In the case of Venezuela, Mexico and Colombia, substantial military capabilities are to be observed, which is reflected in their high position in the ranking. The position of a leader belongs to Brazil, which outweighs other countries in the region as far as major military equipment goes and has only slightly lower number of army personnel than Colombia (see Table 3).

Considering the wholistic military capability of Brazil, Venezuela, and to a smaller extent, Peru, Chile, and Argentina, it can be concluded that land forces of these countries enable them to take defensive and offensive military actions. Interestingly, in the case of Colombia, whose army if often referred to as "one large infantry regiment", and Mexico, land forces are mainly of defensive nature or they are destined to perform intervention/pacification operations within their territories (for instance operations against irregular forces and, to a smaller extent, operations outside their borders). As far as other countries are concerned (excluding Cuba), their land forces enable them to take various defensive actions.

\section{Air force ranking}

On the regional scale, air force does not constitute the main component of the armies of Latin America and the Caribbean. According to IISS, air force capability of the region was quite varied. Antigua and Barbuda, Barbados, Haiti, the Bahamas do not possess this type of armed forces. Considering qualitative and quantitative factors, Belize, Trinidad and Tobago, Guyana, Jamaica, and Nicaragua did not have any air force, whereas Surinam, Guatemala owned only small amount. Air force in these countries is practically non-existent and
The Military Standing of the Countries in Latin America and the Caribbean Region in the Period Between 2008-2020

Ireneusz Topolski 
Table 3.

The number of soldiers and basic military equipment categories of land forces of the chosen countries in 2020, according to IISS

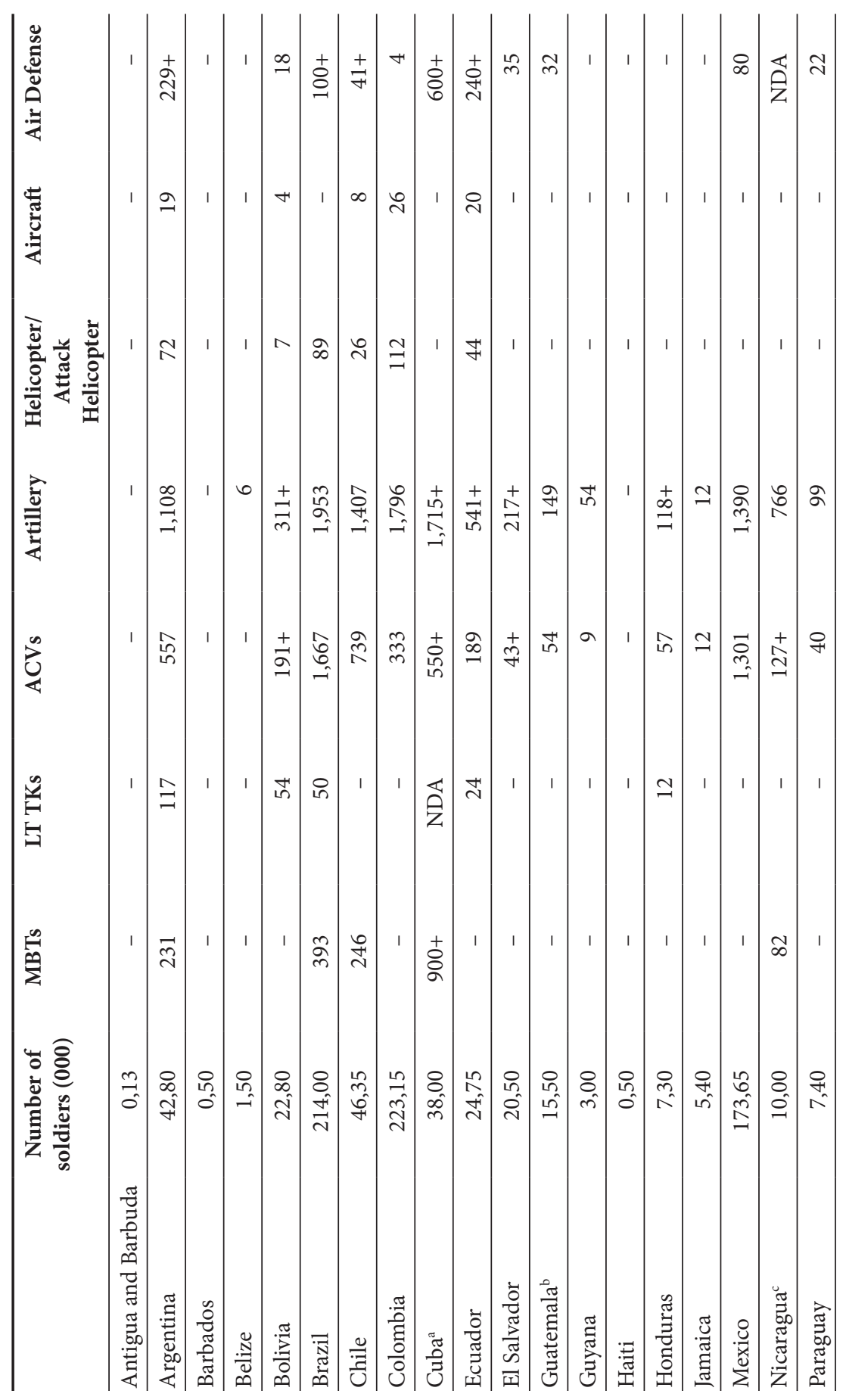




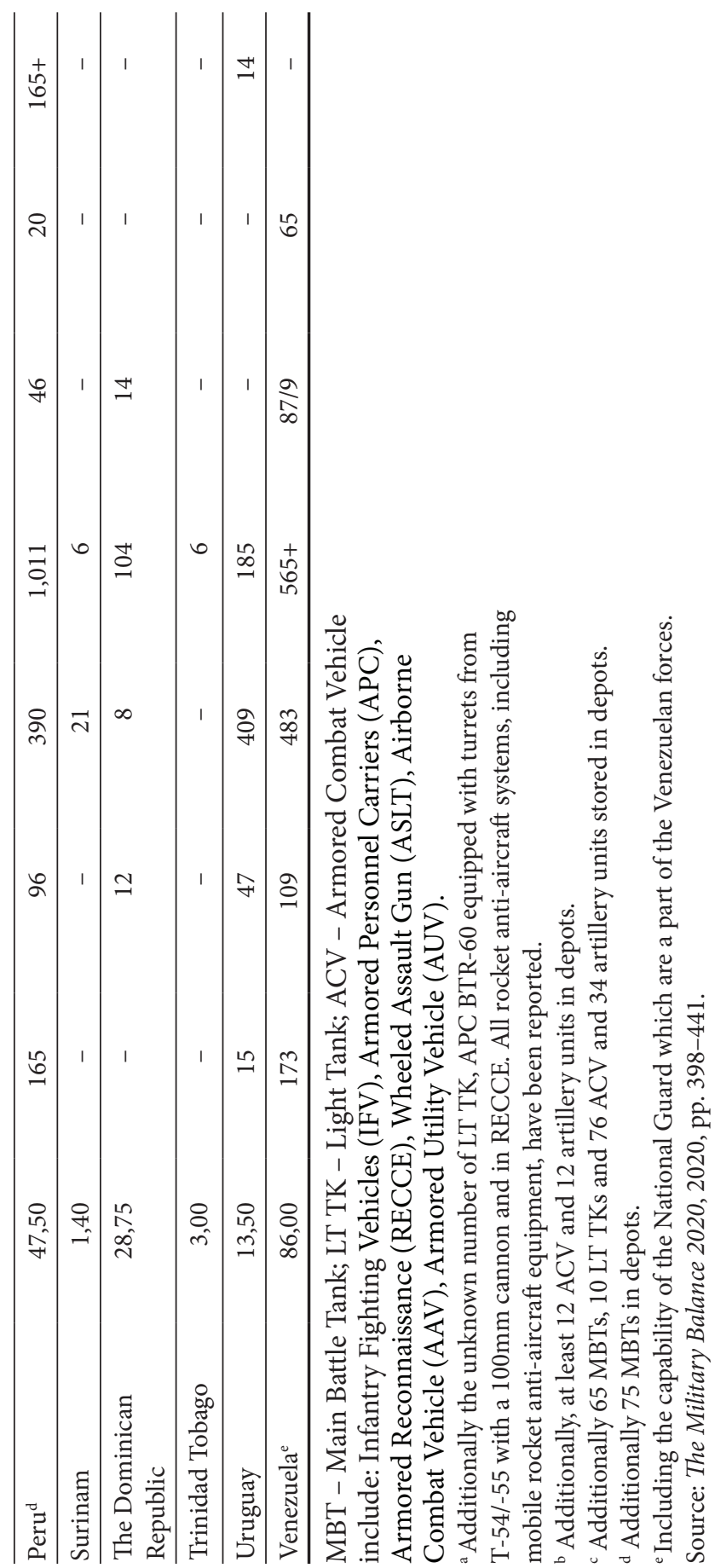

The Military Standing of the Countries in Latin America and the Caribbean Region in the Period Between 2008-2020

Ireneusz Topolski 
their position in the region was merely symbolic. The Air Force of the Dominican Republic, Paraguay and Uruguay has only a small number of aircraft available (not in the multi-role combat aircraft/fighter category, though). The air forces of the above-mentioned 14 countries are not capable of independently protecting their territory from aerial attack. Honduras, El Salvador, and Bolivia also exhibited a very limited air force capability. The position of these three countries could be described as low in the region, yet it is much higher than e.g. Belize or Jamaica or any country from that group. Argentina, Ecuador, Cuba, and Mexico have much greater capability including combat aircra$\mathrm{ft}$, helicopters, and anti-aircraft. However, Argentina and Mexico did not possess multi-role aircraft and the technical condition of Cuba's aircraft is hard to determine and some of its inventory is definitely obsolete. Basing the analysis on qualitative and quantitative factors, these countries reached a rather mediocre position in the ranking. The capability of Colombia could be said to be average, while Peru, Chile, and Venezuela place slightly higher, reaching the position of moderately high level of capability. The deciding components in these cases seem to be related to the quantity and quality of equipment. In the case of Venezuela, the great number of anti-aircraft is worth noticing. As for the aircraft capability, Brazil is at the top of the list, compared to the other countries (see Table 4). Brazilian forces' main asset is their offensive potential, yet this country does not have modern multi-role aircraft. Those are owned by Peru, Chile, and Venezuela (several dozen units each) (The Military Balance 2020, 2020, pp. 398-441). The relevant question concerns the technical condition of aircraft in respective countries. Secondly, air force is mainly prepared to carry out operations within its own territory, to support land forces and, to some extent, to attack non-public, armed military formations. Only a few of the countries can counter modern aircraft of a potential enemy. In conclusion, a few of Latin America and the Caribbean's countries, particularly Colombia, Argentina, Brazil ${ }^{4}$ (and, to a smaller extent, Chile, Peru and Ecuador) in order to strengthen the air force need modern combat aircraft - especially multirole aircraft, which requires a lot of financial resources.

\section{Naval forces ranking}

For countries located in Latin America and the Caribbean naval forces - both of military and police nature - play a particularly important role. Bolivia and Paraguay do not have access to the sea, still, they own this type of forces operating on rivers. Belize, Costa Rica, and Panama only maintain paramilitary formations. It should be noted that in countries of the region the naval forces

4 Brazil signed a contract with Sweden by means of which it purchased 36 multi-role fighters of JAS 39E/F type Gripen (Gripen NG). They will start gradually being introduced to the Brazilian air force from 2021 (see Brazil Air Force, 2015). 


\begin{tabular}{|c|c|c|c|c|c|}
\hline & $\begin{array}{l}\text { Personnel } \\
\quad(000)\end{array}$ & $\begin{array}{c}\text { Combat } \\
\text { Aircraft/ } \\
\text { Aircraft }\end{array}$ & $\begin{array}{c}\text { Helicopters/ } \\
\text { Attack } \\
\text { Helicopters }\end{array}$ & Air Defense & UAV \\
\hline Argentina & 12,90 & $42 / 114$ & $39 /-$ & 88 & - \\
\hline Belize & NDA & $-/ 3$ & $3 /-$ & - & - \\
\hline Bolivia & 6,50 & $22 / 118$ & $36 /-$ & $18+$ & \\
\hline Brazil & 67,50 & $209 / 612$ & $73 / 12$ & - & 5 \\
\hline Chile & 11,05 & $90 / 167$ & $40 /-$ & $17+$ & 3 \\
\hline Colombia & 13,65 & $72 / 203$ & $95 /-$ & - & 8 \\
\hline $\mathrm{Cuba}^{\mathrm{a}}$ & 8,00 & $44 / 101$ & $14 / 4$ & NDA & - \\
\hline Ecuador & 6,40 & $42 / 95$ & $11 /-$ & $105+$ & - \\
\hline El Salvador & 2,00 & $25 / 46$ & $28 /-$ & - & - \\
\hline Guatemala $^{\mathrm{b}}$ & 1,00 & $1 / 17$ & $13 /-$ & - & - \\
\hline Guyana & 0,20 & $-/ 6$ & $3 /-$ & - & - \\
\hline Honduras & 2,30 & $17 / 50$ & $15 /-$ & 48 & - \\
\hline Jamaica & 0,25 & -15 & $8 /-$ & - & - \\
\hline Mexico & 8,00 & $76 / 265$ & $182 /-$ & - & 8 \\
\hline Nicaragua & 1,20 & $-/ 11$ & 9/- & 18 & - \\
\hline Paraguay & 2,75 & $6 / 39$ & $12 /-$ & - & - \\
\hline Peru & 9,50 & $77 / 179$ & $70 / 18$ & NDA & - \\
\hline Surinam & 0,20 & $2 / 3$ & $3 /-$ & - & - \\
\hline $\begin{array}{l}\text { The Dominican } \\
\text { Republic }\end{array}$ & 16,10 & $8 / 26$ & $25 /-$ & 4 & - \\
\hline $\begin{array}{l}\text { Trinidad } \\
\text { Tobago }\end{array}$ & 0,05 & -12 & $3 /-$ & - & - \\
\hline Uruguay & 2,60 & $13 / 53$ & $11 /-$ & - & - \\
\hline Venezuela $^{c}$ & 11,50 & $82 / 204$ & $30 /-$ & $440+$ & - \\
\hline
\end{tabular}

The Military Standing of the Countries in Latin America and the Caribbean Region in the Period Between 2008-2020

Ireneusz Topolski
Table. 4.

The number of soldiers and basic ordnance categories of air force of the chosen countries in 2020, according to IISS

UAV - Unmanned Aerial Vehicles.

a Additionally, there are 179 combat aircraft (204 units in total) and 25 helicopters 'instore', including 8 attack helicopters.

b Additionally 9 aircraft in depots.

c The number of rocket anti-aircraft has not been provided.

Source: The Military Balance 2020, 2020, pp. 398-441. 
operate on various seas (up to two different ones; in the case of Mexico, on three) which, thus, determines the denotation of their military stature. Naval forces of the Bahamas, the Dominican Republic, Barbados, Antigua and Barbuda, Trinidad and Tobago, Venezuela, Guyana, Surinam, Brazil, Uruguay, Argentina and possibly Chile may operate in the Atlantic Ocean - in its northern, central and southern parts, respectively. In the Pacific operate the forces of Mexico, Guatemala, El Salvador, Honduras, Nicaragua, Colombia, Ecuador, Peru, Chile, and Argentina. The Navy of Mexico, Cuba, the Dominican Republic, Jamaica, Guatemala, Honduras, Nicaragua, El Salvador, Venezuela, Colombia, Antigua and Barbuda operate on the Caribbean Sea waters. Lastly, Mexican and Cuban forces operate on the Mexican Bay.

Capability of naval forces ${ }^{5}$ of the countries in the region of Latin America and the Caribbean is varied, but not so much as land forces, or air force. Brazil, whose naval capability is sufficient to defend its own coast and take offensive actions on parts of the Atlantic Ocean with the support of its own air force, holds the first place in the ranking. The main assets are undoubtedly principle surface combatants, submarines, and universal assault ships. Limited ability to operate on oceans, far away from own bases and without air support might be treated as drawbacks. Satisfying Brazil's power projection ambitions requires to have at least one fully operational aircraft carrier. Compared to land forces and air force, Brazil does not have such a big advantage over the other countries in the region. To determine the position of these remining countries in the ranking is a difficult task since naval forces of Peru, Argentina, Chile, Venezuela, Colombia and, to some degree, Mexico all have various assets. An additional issue is the technical condition of ships and the level of crew's martial training. Moreover, the Colombian, Venezuelan and Mexican naval forces operate on at least two different bodies of water - The Pacific, Mexican Bay, the Caribbean Sea and the Atlantic. Colombian assets are as follows: rank 2 regarding the number of personnel, rank 4 in guardships, coastal defense and submarines categories, respectively. In comparison with the other countries of the region Colombia does not have principal surface combatants and corvettes of high offensive power and its naval aviation is rather weak. The Mexican Navy possesses the greatest number of warships in the region, and in the category of personnel it is only preceded by Brazil while being comparable to Colombia's forces. Mexico owns powerful naval aviation forces (excluding combat aircra$\mathrm{ft}$ ) and the biggest number of guardships considerably outnumbering other countries in the region. This capability is enough to protect the coastal area of the country. The main drawback stems from the fact that the Mexican Navy completely lacks large offensive vessels. In respect of the number of guardships and coastal defense ${ }^{6}$, Venezuela is only preceded by Mexico and Chile. Their

5 Marine corps is a crucial component of naval forces (see more Moloeznik, 2018, pp. 147-160).

6 On the $30^{\text {th }}$ of March 2020 patrol ship ANBV „Naiguá” of Venezuelan naval forces sank trying to ram passenger ship RCGS “Resolute” (see Venezuelan Navy, 2020). 
fleet includes frigates and submarines. As a drawback, one must notice the relatively weak naval aviation and a small number of submarines. Taking into the account the quality of naval units, Peruvian forces are considerable. The country's Navy has the biggest number of submarines at its disposal, quite a lot of frigates, corvettes and guardships. On the scale of the region, it has the crucial offensive advantages. Compared to Peru, Chile has significantly fewer corvettes, yet the number of guardships is considerably bigger - the second place in the region. Argentinian naval forces possess substantial offensive power, yet its shortcomings can be found in the small number of guardships, coastal defense and submarines. The Navy of Ecuador and Uruguay have lower naval capabilities. Trinidad and Tobago, the Bahamas and the Dominican Republic have a large number of guardships and coastal defense vessels which enables them to take defensive actions and to take control over bodies of water. Antigua and Barbuda, Barbados, Guyana, Jamaica, as well as Nicaragua, Surinam, Cuba, El Salvador, Guatemala, and Honduras occupy a very low position in the region (see Table 5). Naval forces of Latin America and the Caribbean are characterized by a relatively large number of surface combatants, corvettes and above all, guardships and coastal defense ships, including the ocean-going ones. Taking into the consideration the size of the countries of the region, their naval forces can be described as at least average. The naval forces of Brazil, Argentina, Peru, Chile, Venezuela, Colombia, Ecuador, and to a limited extent, Uruguay, have large offensive ocean-going ships.
The Military Standing of the Countries in Latin America and the Caribbean Region in the Period Between 2008-2020

Ireneusz Topolski 
The number of soldiers and

Table 5.

basic military equipment categories of naval forces of the chosen countries in 2020, according to IISS

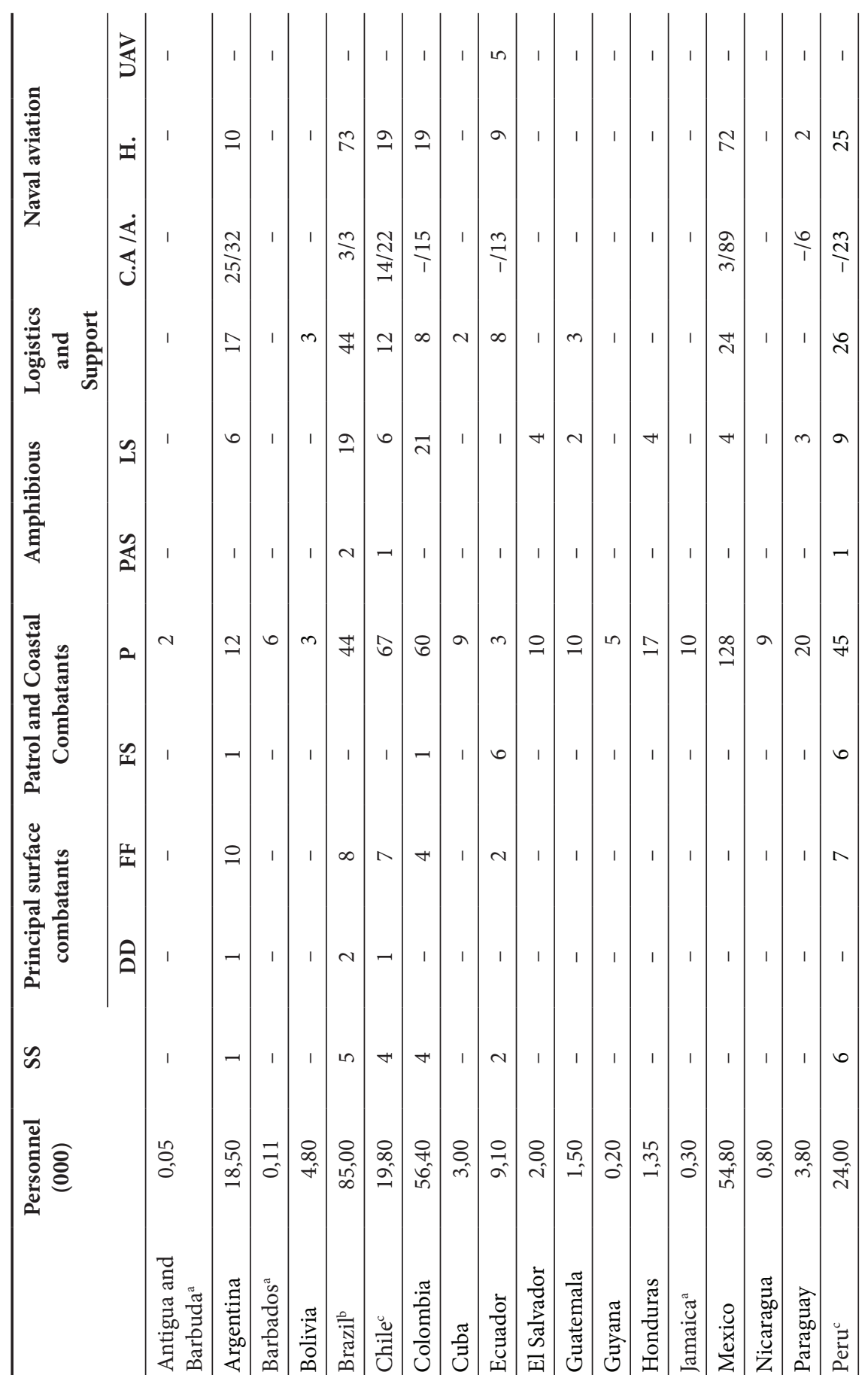




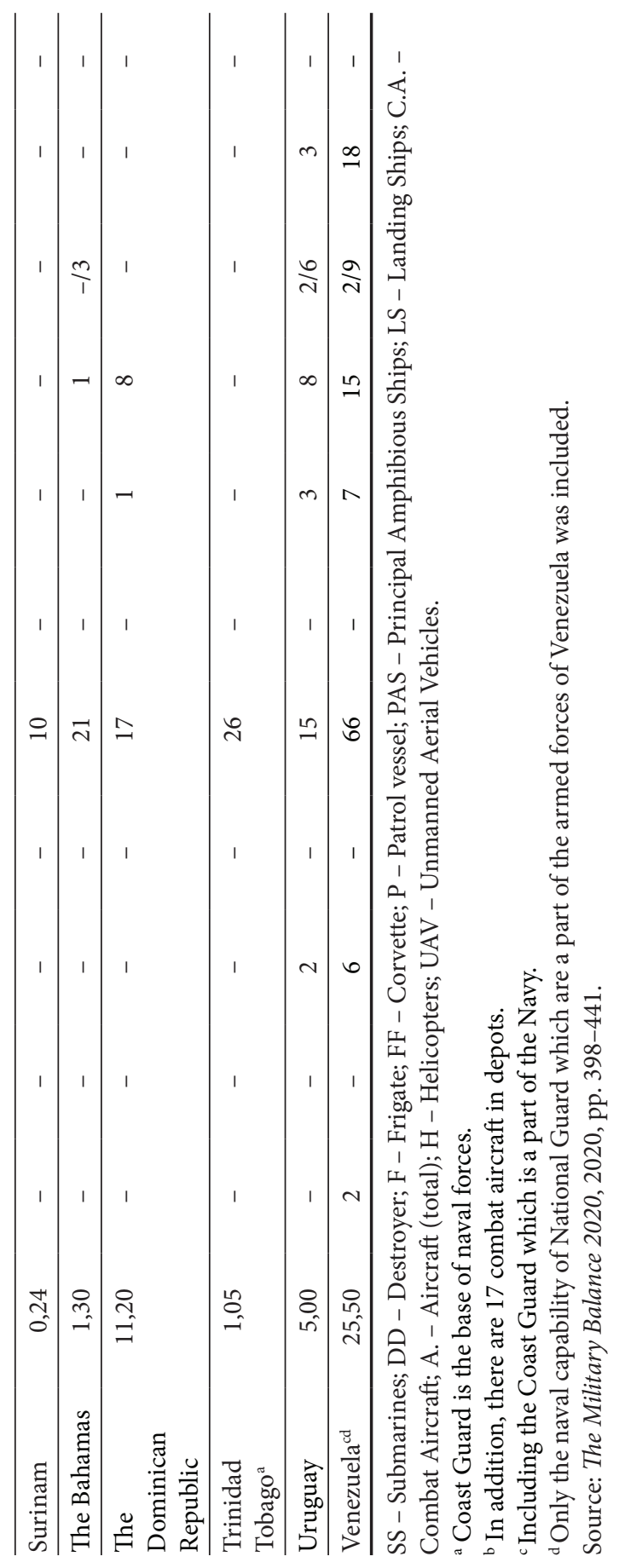

The Military Standing of the Countries in Latin America and the Caribbean Region in the Period Between 2008-2020

Ireneusz Topolski 


\section{Paramilitary forces ranking}

Paramilitary structures with their personnel and military equipment reinforce the armed forces of the countries in the region considerably. First of all, paramilitary forces could be described as the so-called „second army" since in the majority of the countries paramilitary formations are very well-developed ${ }^{7}$. Secondly, in the case of Costa Rica and Panama the whole national defense is grounded on them. Furthermore, Antigua and Barbuda, the Bahamas, Barbados, Nicaragua, Surinam, Trinidad and Tobago, Jamaica and Guyana do not have such forces (since 2013). According to IISS data, the military stature of paramilitary formations in the countries of Latin America and the Caribbean was greatly varied between 2008-2020. The most numerous paramilitary forces could be found in Brazil - 386,000-395,000 personnel. On the scale of the region, significant forces could also be found in Venezuela ${ }^{8}-150,000-220,000$ (since 2016), Colombia - 144,000-188,000, Mexico - 31,000-132,000. In other countries, including Peru with 77,000-84,000 of personnel, and Chile (38,000-45,000), there are greater disproportions. Lower positions are occupied by: Bolivia (37,000), Argentina (31,000), Cuba (27,000), Panama (12,000-26,000), Guatemala (19,000-25,000), El Salvador (12,000-17,000), Paraguay and the Dominican Republic (15,000 each). Smaller forces belong to Costa Rica $(10,000)$ and Honduras $(8,000)$, followed by scarce forces of Ecuador (400-1,000), Uruguay (900-1,000), Belize (100), Haiti (50-2,700), and Guyana (2,000 - between 2008-2012) (see Table 6).

Consequently, certain regularities can be observed in the analyzed period. Firstly, no process of increasing or decreasing the number of personnel took place in the countries of Latin America and the Caribbean - except for Mexico (to a small extent). Secondly, the reduction in personnel occurred in Haiti (since 2009 it was quite considerable), in Peru (since 2009 - it remained at the same level since then), and in the already mentioned Guyana. Thirdly, comparing 2008 to 2020, one must notice that the number of paramilitary formations increased in Brazil, Venezuela, Colombia, Mexico, Chile, Panama, Guatemala, El Salvador, Ecuador, Uruguay, Belize. In other countries of the region, it remained the same. The largest increase in the number of personnel in paramilitary formations was noted in Venezuela - from 0 to 220,000, and Mexico - from 31,000 to 132,000, which happened at the cost of regular armed forces. The National Guard was supposed to become the elite force responsible for fighting the organized crime (see Derwich, 2019, p. 146). Fourthly, in Brazil, Venezuela, Bolivia (all since 2016), Guatemala and Paraguay paramilitary formations are numerically superior to the armed forces (see Table 1 and 6).

7 According to IISS, only those that are trained and equipped in the same way as regular armed forces and are under military command belong to this group.

8 One must notice the existence of armed, pro-governmental, paramilitary groups - the socalled colectivos, named after Chavez's groups (see Hinz, 2019, pp. 21-23; Surdel, 2019, p. 196). 


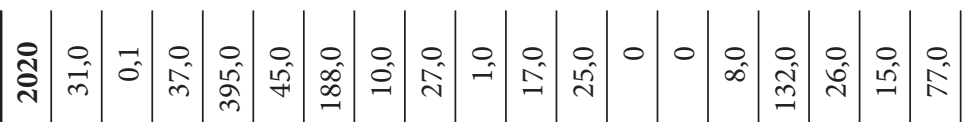

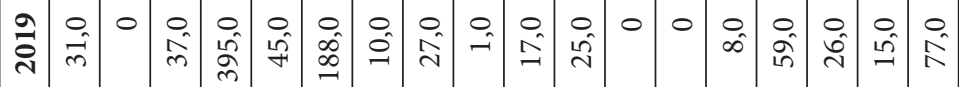

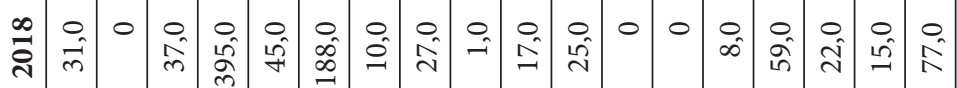

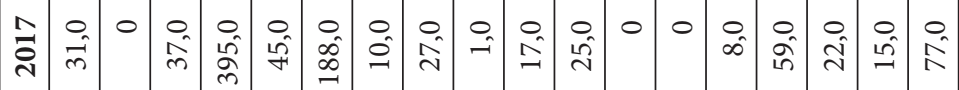

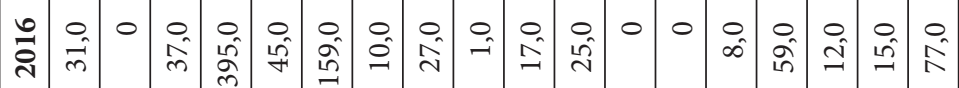

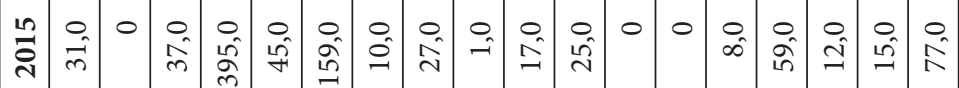

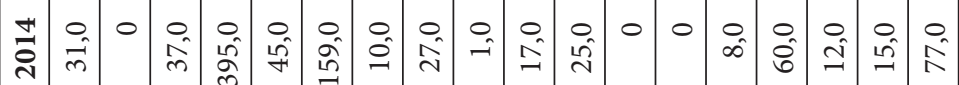

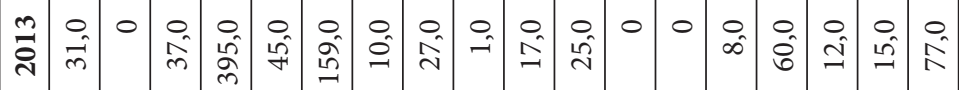

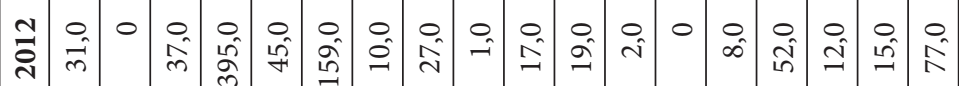

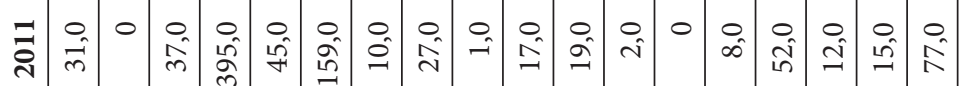

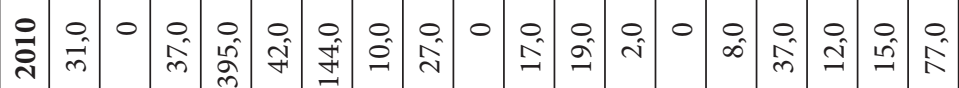

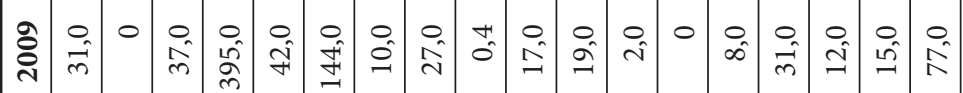

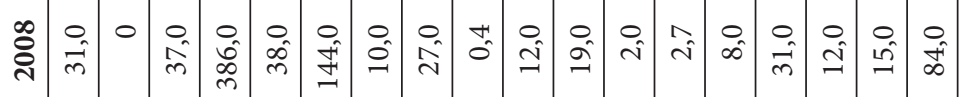

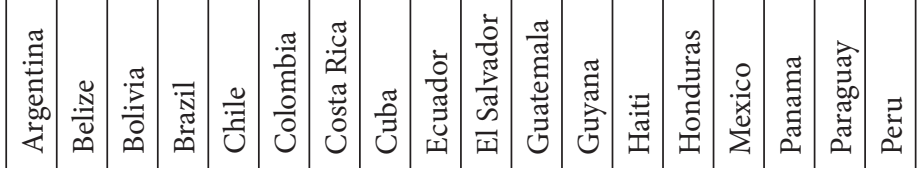

The Military Standing of the Countries in Latin America and the Caribbean Region in the Period Between 2008-2020

Ireneusz Topolski
Table 6.

The number of personnel in paramilitary formations of the chosen countries of Latin America and the Caribbean between 2008-2020, according to IISS (in 000) 


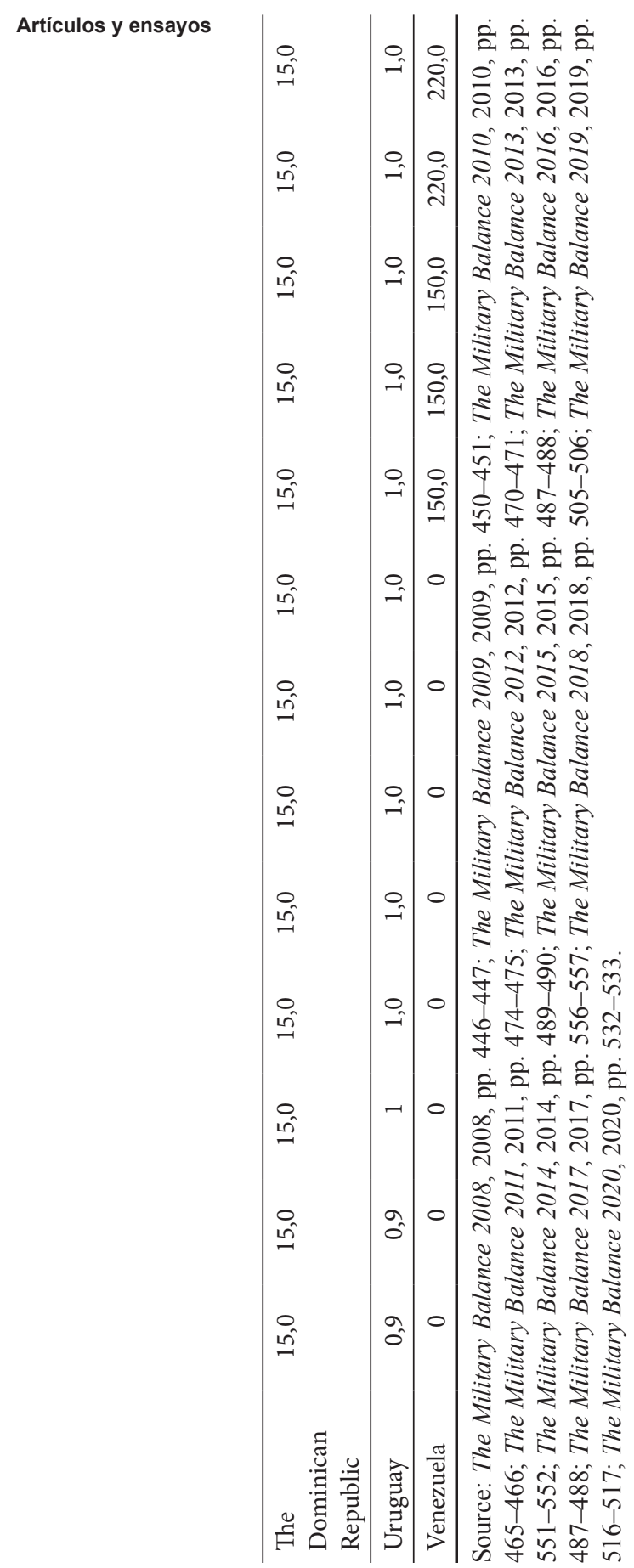




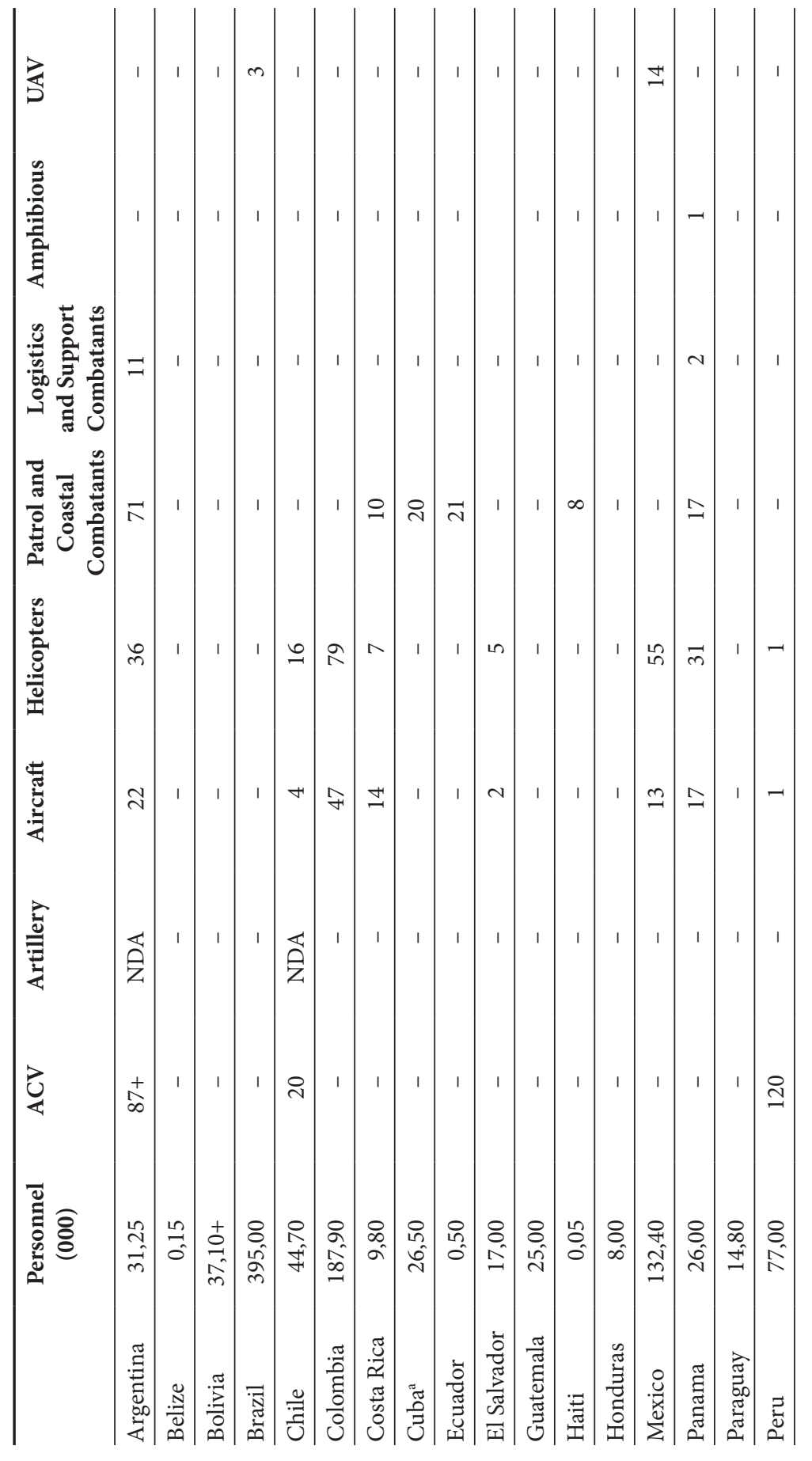

The Military Standing

of the Countries

in Latin America and the Caribbean Region in the Period Between 2008-2020

Ireneusz Topolski
Table 7.

Personnel and military equipment of paramilitary formations of the chosen countries in 2020 
Artículos y ensayos

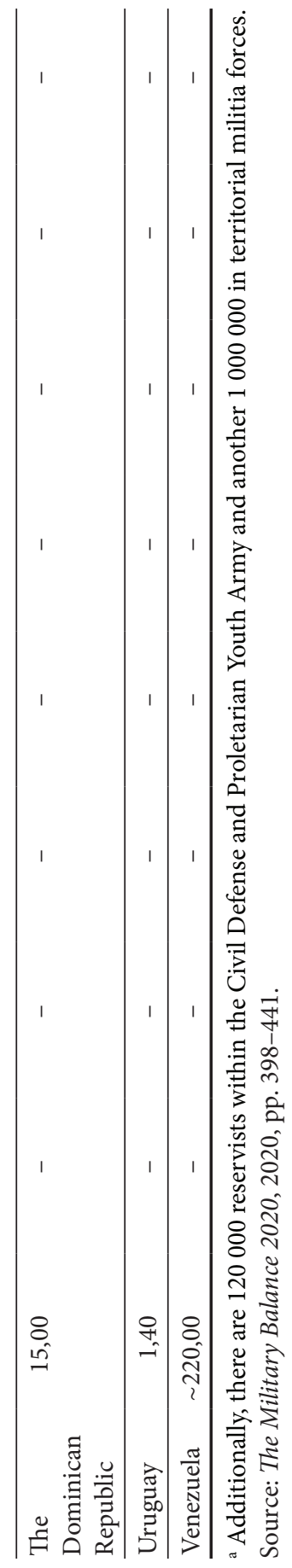


According to IISS, in 2020 there were 395,000 personnel in the Brazilian paramilitary forces (the National Forces of Public Security). The equipment included 3 UAVs. Brazil was the leader in the region as far as the stature of paramilitary forces goes. Venezuela, whose National Bolivarian Militia amounted to 220,000 (in addition, the existence of colectivos must be borne in mind, here $)^{9}$, held the second place. Colombia, with its 187,900 personnel, as well as helicopters and aircraft, is third (National Colombian Police), followed by Mexico - 132,400 personnel and helicopters, aircraft, UAVs. Peru, Chile, Bolivia, and Argentina had significantly smaller forces. In lower positions there were: El Salvador, the Dominican Republic, Paraguay, Costa Rica, and Honduras. In the case of other countries, paramilitary forces were considerably smaller, or even scarce. On the other hand, it must be said that the largest number of military equipment was stored in depots in Argentina (including ACVs, artillery, aircraft, helicopters, patrol, coastal defense, logistics and support combatants). Considerable attention should also be drawn to the paramilitary stature of Peru, Chile, Cuba, and Ecuador. In the region, Costa Rica and Panama possess average number of paramilitary forces; however, one must admit that this is the wholistic military capability of both countries (see Table 7).

\section{Conclusions}

Total military position of the Latin America and Caribbean countries is very varied. The situation is even more complicated because some countries started modernizing military equipment, thus, improving its quality. This is connected with procurements made by the countries involved and also with geographical conditions. What is more, some counties have been trying to introduce standards of democratic control to their armies, which results in their level of professionalism being raised. Moreover, in the region, there is a kind of ongoing "specific" armament race. It must be stressed at this point that one of the biggest shortcomings of Latin American and the Caribbean countries stems from the fact that they lack adequate air force and combat air force - especially up-to-date multi-role fighters - as well as because of a generally very low stature of air force. What is more, the region features well-developed paramilitary formations which play a significant role in helping maintain the existing political systems and internal security level in these countries.

Hypotheses which we formulated in the introduction seem to have been confirmed. Considering the wholistic military capability, international and regional stature of Latin American and the Caribbean countries could be "arbitrarily" described on 10 separate levels. Brazil, which dominates in the region, is ranked first. Brazil's capability is mainly determined by the size of

9 They received weapons from the authorities - there may be dozens beyond control of the security services (see Hinz, 2019, pp. 21-23; Surdel, 2019, p. 196).
The Military Standing

of the Countries

in Latin America and the Caribbean Region in the Period Between 2008-2020

Ireneusz Topolski 
its armed forces, the standing of land forces and military formations, and, to a smaller extent, the stature of the navy and air force. Therefore, Brazil can independently defend its territory and it also has the capacity to deploy abroad, which gives it the status of a regional military power. Level two, despite some disproportions, comprises Colombia, Mexico, and Venezuela. Their military position is weaker than that of Brazil but, compared to other countries in Latin America, it is higher or much higher. Colombia's high position results from the size of its land forces, paramilitary formations, and the navy; the biggest drawbacks being the lack of armored and mechanized forces. Mexico holds rank number 3 which is mainly because it has sizeable land forces, paramilitary formations and, to some extent, naval forces. The biggest disadvantage is its weaker air force position - especially the lack of multipurpose fighters and heavy weapons. Venezuela (rank 4) is a rather problematic case since its military stature is influenced mainly by quantitative factors, such as the number of land forces and paramilitary formations (excluding these, Venezuela would be ranked $5^{\text {th }}$ or $6^{\text {th }}$ ) and also, to some extent, air force and naval forces. The biggest issue seems to be the difficulty in determining the morale of armed forces and the technical condition of military equipment - especially the operational capabilities of combat air force. Armed forces of the level two countries can operate independently to provide national security - however, they meet certain difficulties in protecting their borders and controlling the hard-to-reach areas. On the third level, the following countries can be found: Peru (rank 5), Argentina and Chile (rank 6 and 7 respectively). These countries exhibit considerable military capability in the region, which enables them to take defensive actions against external threats. Peru, in particular, stands out in this group. Level 4 consists of the following countries: Bolivia (8), Ecuador (9) and Cuba (10). Their military ranking could be described as average. On the fifth level, there are: Uruguay (11), Guatemala (12) and the Dominican Republic (13). These countries' military position in the region is below average. The sixth level is occupied by: Honduras (14), Paraguay (15), El Salvador (16) and Panama (17). These countries have limited military capability, hence their rather low military strength. In the seventh group we can find: Nicaragua, Jamaica, and Costa Rica (ranks 18-20). Their military stature is low. This group is followed by level 8 countries, which are: Trinidad and Tobago, Guyana, and Surinam (ranks 21-23). Level 9 countries with a very low military position are: the Bahamas, Barbados and Belize (24-26). These countries have a very limited ability to independently defend themselves against threats. The tenth and last group of countries comprises: Antigua and Barbuda (27) and Haiti (28). Their military stature could be described as merely symbolic; hence they cannot independently provide their national security.

However, there exists a range of unknown factors, such as the level of training and morale of soldiers and the army personnel. The second issue revolves around the operational capabilities (operational readiness) of air force and, to some extent, naval forces of the countries in the region. The character of Latin 
America and the Caribbean relates to a "specific" democratic control exercised over the armed forces. Separate, yet equally crucial issue, which needs to be investigated and researched, revolves around the redefinition of the role of military personnel representatives in the countries of the region. It is mainly connected with the "deterioration of democracy" and the re-appearance of military men as important, "new-old" entities on the political scene of the countries of the region.
The Military Standing of the Countries in Latin America and the Caribbean Region in the Period Between 2008-2020

Ireneusz Topolski

\section{Bibliographical references}

\section{Monographs, studies, and compilations:}

Goldblat, J. (1994). Arms Control. A Guide to Negotiations and Agreements. LondonThousand Oaks-New Delhi: SAGE Publications Ltd.

Kruijt, D. (2017). The Political Influence of the Latin American Military. Amsterdam: CEDLA, Cuadernos, Working Paper, no. 30.

Topolski, I. (2004). Siła militarna w polityce zagranicznej Federacji Rosyjskiej. Lublin: Wydawnictwo Uniwersytetu Marii Curie-Skłodowskiej.

Trefler, P. (2014), Siły zbrojne i polityka w Argentynie, Brazylii i Chile. Historia i współczesność. Toruń: Wydawnictwo Adam Marszałek.

The Military Balance 2008, (2008). London: International Institute for Strategic Studies. The Military Balance 2009, (2009). London: International Institute for Strategic Studies. The Military Balance 2010, (2010). London: International Institute for Strategic Studies. The Military Balance 2011, (2011). London: International Institute for Strategic Studies. The Military Balance 2012, (2012). London: International Institute for Strategic Studies. The Military Balance 2013, (2013). London: International Institute for Strategic Studies. The Military Balance 2014, (2014). London: International Institute for Strategic Studies. The Military Balance 2015, (2015). London: International Institute for Strategic Studies. The Military Balance 2016, (2016). London: International Institute for Strategic Studies. The Military Balance 2017, (2017). London: International Institute for Strategic Studies. The Military Balance 2018, (2018). London: International Institute for Strategic Studies. The Military Balance 2019, (2019). London: International Institute for Strategic Studies. The Military Balance 2020, (2020). London: International Institute for Strategic Studies.

\section{Articles:}

Biczyńska, E. (2019). Kolumbia: Trudny proces pokojowy. In J. Gocłowska-Bolek (Ed.), Panorama wyborcza Ameryki Łacińskiej w 2019 roku. Nowe wyzwania stare problemy? (pp. 124-130). Warszawa: Ośrodek Analiz Politycznych, Uniwersytet Warszawski.

Czerny, A. and Czerny, M. (2017a). Turystyczne regiony transgraniczne - problematyka badawcza na przykładzie granicy trzech państw (Peru, Brazylii i Kolumbii) w zachodniej 

ept.2017.1.37-14.

Czerny, M. (2012). Rozwój przestrzenny Bogoty w napływ wysiedlonych przymusowo $\mathrm{z}$ terenów wiejskich do miast. Ameryka Łacińska, no. 3-4, pp. 31-44.

Czerny, M. (2015). Ameryka Środkowa - trudne sąsiedztwo na przesmyku między Meksykiem a Ameryką Południową. Studia $z$ Geografii Politycznej i Historycznej, vol. 4, pp. 37-54, DOI http://dx.doi.org/10.18778/2300-0562.04.02.

Czerny, M. and Czerny, A. (2017b). Geograficzne aspekty ochrony dziedzictwa kulturowego w Ameryce Łacińskiej. Zeszyty Naukowe Uczelni Vistula, no. 1, Filologia, pp. 40-54.

Derwich, K. (2019). Meksyk: 2018 rok - największa elekcja w historii Meksykańskich Stanów Zjednoczonych. In J. Gocłowska-Bolek (Ed.), Panorama wyborcza Ameryki Łacińskiej w 2019 roku. Nowe wyzwania stare problemy? (pp. 142-147). Warszawa: Ośrodek Analiz Politycznych, Uniwersytet Warszawski.

Gil, G. (2012). Upadłe państwa w Ameryce Łacińskiej - kazus Kolumbii. In K. Krzywicka (Ed.), Dwieście lat niepodległości państw Ameryki Łacińskiej. Perspektywa historyczna i wyzwania współczesności (pp. 111-126). Lublin: Wydawnictwo Uniwersytetu Marii CurieSkłodowskiej.

Gocłowska-Bolek, J. (2019). Wstęp. In J. Gocłowska-Bolek (Ed.), Panorama wyborcza Ameryki Łacińskiej w 2019 roku. Nowe wyzwania stare problemy? (pp. 10-11). Warszawa: Ośrodek Analiz Politycznych, Uniwersytet Warszawski.

Hinz, K. J. (2019). Ameryka Łacińska na rozdrożu. In J. Gocłowska-Bolek (Ed.), Panorama wyborcza Ameryki Łacińskiej w 2019 roku. Nowe wyzwania stare problemy? (pp. 18-29). Warszawa: Ośrodek Analiz Politycznych, Uniwersytet Warszawski.

Krzywicka, K. (2009). Region Ameryki Łacińskiej i Karaibów. In I. Topolski, H. Dumała, A. Dumała (Eds.), Regiony w stosunkach międzynarodowych (pp. 209-236). Lublin: Wydawnictwo Uniwersytetu Marii Curie-Skłodowskiej.

Krzywicka, K. (2012a). Kształtowanie państwa narodowego w Wenezueli - autorytaryzm i militaryzm w scentralizowanym państwie federalnym, In K. Krzywicka (Ed.), Dwieście lat niepodległości państw Ameryki Łacińskiej. Perspektywa historyczna i wyzwania wspótczesności (pp. 51-73.). Lublin: Wydawnictwo Uniwersytetu Marii Curie-Skłodowskiej.

Krzywicka, K. (2012b). Pozycja i rola sił zbrojnych w procesie przekształcania państwa casus Wenezueli. Ameryka Łacińska, no. 1, pp. 3-25.

Krzywicka, K. (2012c). Wprowadzenie. Ameryka Łacińska u progu trzeciego stulecia niepodległości. Perspektywa historyczna i wyzwania współczesności. In K. Krzywicka (Ed.), Dwieście lat niepodległości państw Ameryki Łacińskiej. Perspektywa historyczna i wyzwania współczesności (pp. 7-25). Lublin: Wydawnictwo Uniwersytetu Marii CurieSkłodowskiej.

Lisińska, M. (2017). Stany bezpieczeństwa w Ameryce Łacińskiej w 2016 roku. Przegląd Strategiczny, no. 10, pp. 529-545, DOI: 10.14746/ps.2017.1.28.

Łaciński, P. (2012). Systemy polityczne państw latynoamerykańskich - refleksje z perspektywy dwustolecia niepodległości Ameryki Łacińskiej. In K. Krzywicka (Ed.), Dwieście lat niepodległości państw Ameryki Łacińskiej. Perspektywa historyczna i wyzwania współczesności (pp. 29-50). Lublin: Wydawnictwo Uniwersytetu Marii Curie-Skłodowskiej.

Łaciński, P. (2017). Wyzwania i uwarunkowania stabilności geopolitycznej Ameryki Łacińskiej. Ameryka Łacińska, no. 3, pp. 5-17. 
Martynov, B. F. and Moloeznik, M. P. (2017). Mexico on a criminal traffic scenario. MGIMO Review of International Relations, no. 2, pp. 184-194. Retrieved April 15, 2020, from https:// www.researchgate.net/publication/317507134_Mexico_On_A_Criminal_Traffic_Sc enario, DOI: 10.24833/2071-8160-2017-2-53-184-194.

Mata, L. J. and Campos, M. (2001). Latin America. In J. J. McCarthy, O. F. Canziani, N. A. Leary, D. J. Dokken, K. S. White (Eds.), Climate Change 2001: Impacts, Adaptation and Vulnerability (pp. 696-734). Cambridge: Cambridge University Press. Retrieved May 7, 2020, from https://library.harvard.edu/collections/ipcc/docs/27_WGIITAR_FINAL.pdf.

Moloeznik, M. P. (2018). Latin America Marine Corps: Between the Past and the Future. Relaciones Internacionales, no. 55, pp. 147-163. Retrieved May 7, 2020, from https:// revistas.unlp.edu.ar/RRII-IRI/article/download/5598/5390/.

Olszanecka, N. (2018). Armia jako grupa interesu. Problem stosunków cywilnowojskowych. Athenaeum. Polskie Studia Politologiczne, vol. 57, pp. 171-182, DOI: 10.15804/ athena.2018.57.10.

Spyra, J. (2019). Urugwaj: Nowe wyzwania. In J. Gocłowska-Bolek (Ed.), Panorama wyborcza Ameryki Łacińskiej w 2019 roku. Nowe wyzwania stare problemy? (pp. 184-190). Warszawa: Ośrodek Analiz Politycznych, Uniwersytet Warszawski.

Stelmach, M. (2012). Stosunki cywilno-wojskowe w Ameryce Środkowej w XXI wieku. In K. Krzywicka (Ed.), Dwieście lat niepodległości państw Ameryki Łacińskiej. Perspektywa historyczna i wyzwania współczesności (pp. 127-145). Lublin: Wydawnictwo Uniwersytetu Marii Curie-Skłodowskiej.

Stelmach, M. (2019). Wojskowi i polityka w Ameryce Łacińskiej na przełomie XX i XXI wieku. Athenaeum. Polskie Studia Politologiczne, vol. 61, pp. 194-206, DOI: 10.15804/ athena.2019.61.11.

Surdel, T. (2019). Wenezuela: Meandry wenezuelskiej władzy. In J. Gocłowska-Bolek (Ed.), Panorama wyborcza Ameryki Łacińskiej w 2019 roku. Nowe wyzwania stare problemy? (pp. 192-200). Warszawa: Ośrodek Analiz Politycznych, Uniwersytet Warszawski.

Trefler, P. (2007). Siły zbrojne Chile w okresie transformacji demokratycznej. Ameryka Łacińska, no. 1, pp. 64-70.

Tulchin, J. (2019). Nowa definicja bezpieczeństwa narodowego na Półkuli Zachodniej: rola multilateralizmu. Ameryka Eacińska, no. 1,pp.92-99,DOI: 10310.36551/20811152.2019.103.

\section{Internet sources:}

Brazil Air Force, (2015). Sweden, Brazil Pursue Deeper Cooperation With f \$4.7B Gripen NG Deal. Defense News. Retrieved April 25, 2020, from https://www.defensenews.com/ home/2015/10/24/sweden-brazil-pursue-deeper-cooperation -with-4-7b-gripen-ng-deal/.

Latinobarómetro, (2018). Informe 2018. Santiago de Chile: Corporación Latinobarómetro. Retrieved May 7, 2020, from http://www.latinobarometro.org/latdocs/INFORME_2018_ LATINOBAROMETRO.pdf.

Maroszek, M. (2009). Wyścig zbrojeń w Ameryce Łacińskiej?. Biuletyn Opinie, no. 36. Retrieved March 13, 2020, from http://fae.pl/biuletynopiniewyscigzbrojen wamerycelacinskiej.pdf.

Ranking, (2008). Ranking of Military and Police Contributions to UN Operations. Month of Report: 31-Jan-08. Retrieved March 31, 2020, from https://peacekeeping.un.org/sites/ default/files/jan08_2.pdf.
The Military Standing

of the Countries

in Latin America and the Caribbean Region in the Period Between 2008-2020

Ireneusz Topolski 
Ranking, (2009). Ranking of Military and Police Contributions to UN Operations Month of Report: 31-Jan-09. Retrieved March 31, 2020, from https://peacekeeping.un.org/sites/ default/files/jan09_2.pdf.

Ranking, (2010). Ranking of Military and Police Contributions to UN Operations Month of Report: 31-Jan-10. Retrieved March 31, 2020, from https://peacekeeping.un.org/sites/ default/files/jan10_2.pdf.

Ranking, (2011). Ranking of Military and Police Contributions to UN Operations Month of Report: 31-Jan-11. Retrieved March 31, 2020, from https://peacekeeping.un.org/sites/ default/files/jan11_2.pdf.

Ranking, (2012). Ranking of Military and Police Contributions to UN Operations Month of Report: 31-Jan-12. Retrieved March 31, 2020, from https://peacekeeping.un.org/sites/ default/files/jan12_2.pdf.

Ranking (2013). Ranking of Military and Police Contributions to UN Operations Month of Report: 31-Jan-13. Retrieved March 31, 2020, from https://peacekeeping.un.org/sites/ default/files/jan13_2.pdf.

Ranking, (2014). Ranking of Military and Police Contributions to UN Operations Month of Report: 31-Jan-14. Retrieved March 31, 2020, from https://peacekeeping.un.org/sites/ default/files/jan14_2.pdf.

Ranking, (2015). Ranking of Military and Police Contributions to UN Operations Month of Report: 31-Jan-15. Retrieved March 31, 2020, from https://peacekeeping.un.org/sites/ default/files/jan15_2.pdf.

Ranking, (2016). Ranking of Military and Police Contributions to UN Operations Month of Report: 31-Jan-16. Retrieved March 31, 2020, from https://peacekeeping.un.org/sites/ default/files/jan16_2.pdf.

Ranking, (2017). Ranking of Military and Police Contributions to UN Operations Month of Report: 31-Jan-17. Retrieved March 31, 2020, from https://peacekeeping.un.org/sites/ default/files/jan17_2.pdf.

Summary Countries, (2018). Summary of Troop Contributing Countries by Ranking. Police, UN Military Experts on Mission, Staff Officers and Troops 31/01/2018. Retrieved March 31, 2020, from https://peacekeeping.un.org/sites/default/files/ranking_of_military_ and_police_contributions.pdf.

Summary Countries, (2019). Summary of Troop Contributing Countries by Ranking. Police, UN Military Experts on Mission, Staff Officers and Troop 31/01/2019. Retrieved March 31, 2020, from https://peacekeeping.un.org/sites/default/files/2_country_ranking_9.pdf.

Summary Countries, (2020). Summary of Troops Contributing Countries by Ranking Police, UN Military Experts on Mission, Staff Officers and Troops. Retrieved March 31, 2020, from https://peacekeeping.un.org/sites/default/files/2_country_ranking_13.pdf.

Summary Mission, (2018). Summary of Contributions to Peacekeeping by Mission, Country and Post Police, UN Military Experts on Mission and Troops: 31/01/2018. Retrieved March 31, 2020, from https://peacekeeping.un.org/sites/default/files/missions_ detailed_by_country.pdf.

Summary Mission, (2019). Summary of Contributions to Peacekeeping by Mission, Country and Post Police, UN Military Experts on Mission and Troops: 31/01/2019. Retrieved March 31, 2020, from https://peacekeeping.un.org/sites/default/files/5_mission_ and_country_12.pdf. 
Summary Mission, (2020). Summary of Contribution to UN Peacekeeping by Country, Mission and Post. Police, UN Military Experts on Mission, Staff Officers and Troops 31/01/2020. Retrieved March 31, 2020, from https://peacekeeping.un.org/sites/default/ files/3_country_and_mission_16.pdf.

UN, (2008). UN Mission's Contributions by Country. Month of Report: 31-Jan-08. Retrieved March 31, 2020, from https://peacekeeping.un.org/sites/default/files/jan08_5.pdf.

UN, (2009). UN Mission's Contributions by Country. Month of Report: 31-Jan-09. Retrieved March 31, 2020, from https://peacekeeping.un.org/sites/default/files/jan09_5.pdf.

UN, (2010). UN Mission's Contributions by Country. Month of Report: 31-Jan-10. Retrieved March 31, 2020, from https://peacekeeping.un.org/sites/default/files/jan10_5.pdf.

UN, (2011). UN Mission's Contributions by Country. Month of Report: 31-Jan-11. Retrieved March 31, 2020, from https://peacekeeping.un.org/sites/default/files/jan11_5.pdf.

UN, (2012). UN Mission's Contributions by Country. Month of Report: 31-Jan-12. Retrieved March 31, 2020, from https://peacekeeping.un.org/sites/default/files/jan12_5.pdf.

UN, (2013). UN Mission's Contributions by Country. Month of Report: 31-Jan-13. Retrieved March 31, 2020, from https://peacekeeping.un.org/sites/default/files/jan13_5.pdf.

UN, (2014). UN Mission's Contributions by Country. Month of Report: 31-Jan-14. Retrieved March 31, 2020, from https://peacekeeping.un.org/sites/default/files/jan14_5.pdf.

UN, (2015), UN Mission's Contributions by Country. Month of Report: 31-Jan-15. Retrieved March 31, 2020, from https://peacekeeping.un.org/sites/default/files/jan15_5.pdf.

UN, (2016). UN Mission's Contributions by Country. Month of Report: 31-Jan-16. Retrieved March 31, 2020, from https://peacekeeping.un.org/sites/default/files/jan16_5.pdf.

UN, (2017). UN Mission's Contributions by Country. Month of Report: 31-Jan-17. Retrieved March 31, 2020, from https://peacekeeping.un.org/sites/default/files/jan17_5.pdf.

Venezuelan Navy, (2020). Venezuelan patrol vessel sinks after colliding with cruise ship. Naval Today. Retrieved April 25, 2020, from https://navaltoday.com/2020/04/06/ venezuelan-patrol-vessel-sinks-after-colliding-with-cruise-ship/.
The Military Standing

of the Countries

in Latin America and the Caribbean Region in the Period Between 2008-2020

Ireneusz Topolski 